\title{
Pest categorisation of Leucinodes orbonalis
}

\author{
EFSA Panel on Plant Health (PLH), \\ Claude Bragard, Francesco Di Serio, Paolo Gonthier, Josep Anton Jaques Miret, \\ Annemarie Fejer Justesen, Christer Sven Magnusson, Panagiotis Milonas, \\ Juan A Navas-Cortes, Stephen Parnell, Roel Potting, Philippe Lucien Reignault, \\ Hans-Hermann Thulke, Wopke Van der Werf, Antonio Vicent Civera, Jonathan Yuen, \\ Lucia Zappalà, Jean-Claude Gregoire, Chris Malumphy, Ewelina Czwienczek, Andrea Maiorano \\ and Alan MacLeod
}

\begin{abstract}
The EFSA Panel on Plant Health performed a pest categorisation of the eggplant fruit and shoot borer, Leucinodes orbonalis Guenée, (Lepidoptera: Crambidae), for the territory of the EU. L. orbonalis is a tropical and sub-tropical species native to Asia and Australia with India considered its centre of origin. Following taxonomic revision, literature reporting $L$. orbonalis from sub-Saharan Africa should be regarded as referring to members of a complex of other species of Leucinodes native to Africa and not as referring to $L$. orbonalis. $L$. orbonalis is not present in the $E U$ and is not a regulated EU pest. L. orbonalis is a major pest of Solanum melongena (eggplant) in Asia where larvae feed within leaves, stems, shoots and fruits. Larvae can also feed on a range of other plants, mostly within Solanaceae although $L$. orbonalis is generally not reported as a pest of crops other than $S$. melongena. However, in recent years $L$. orbonalis has emerged as a pest of Solanum tuberosum in south-west India. In tropical areas there can be 10 generations per year if conditions are suitable. L. orbonalis has been intercepted 350 times in the EU from a range of Asian countries on a range of produce, mostly larvae in fruits of S. melongena. Biotic factors (host availability) and abiotic factors (climate suitability) suggest that some small areas of the EU could be suitable for establishment. Adult $L$. orbonalis can fly and the species could spread within the EU. The introduction of $L$. orbonalis into the EU would have an economic impact, most likely on $S$. melongena production, the magnitude of which is uncertain. Measures are available to prevent the entry of $L$. orbonalis into the EU. $L$. orbonalis satisfies the criteria that are within the remit of EFSA to assess for this species to be regarded as a potential Union quarantine pest.
\end{abstract}

(c) 2021 European Food Safety Authority. EFSA Journal published by John Wiley and Sons Ltd on behalf of European Food Safety Authority.

Keywords: Aubergine, Brinjal fruit and shoot borer, Eggplant fruit borer, interceptions, pest risk, quarantine, Solanum melongena

Requestor: European Commission

Question number: EFSA-Q-2021-00376

Correspondence: alpha@efsa.europa.eu 
Panel members: Claude Bragard, Francesco Di Serio, Paolo Gonthier, Josep Anton Jaques Miret, Annemarie Fejer Justesen, Alan MacLeod, Christer Sven Magnusson, Panagiotis Milonas, Juan A NavasCortes, Stephen Parnell, Roel Potting, Philippe L Reignault, Hans-Hermann Thulke, Wopke Van der Werf, Antonio Vicent Civera, Jonathan Yuen and Lucia Zappalà.

Declarations of interest: The declarations of interest of all scientific experts active in EFSA's work are available at https://ess.efsa.europa.eu/doi/doiweb/doisearch.

Acknowledgements: EFSA wishes to acknowledge Caterina Campese for her contribution to the establishment section.

Suggested citation: EFSA PLH Panel (EFSA Panel on Plant Health), Bragard C, Di Serio F, Gonthier P, Jaques Miret JA, Justesen AF, Magnusson CS, Milonas P, Navas-Cortes JA, Parnell S, Potting R, Reignault PL, Thulke H-H, Van der Werf W, Vicent Civera A, Yuen J, Zappalà L, Gregoire J-C, Malumphy C, Czwienczek E, Maiorano A and MacLeod A, 2021. Scientific Opinion on the pest categorisation of Leucinodes orbonalis. EFSA Journal 2021;19(11):6890, 28 pp. https://doi.org/10.2903/j.efsa.2021. 6890

ISSN: $1831-4732$

(c) 2021 European Food Safety Authority. EFSA Journal published by John Wiley and Sons Ltd on behalf of European Food Safety Authority.

This is an open access article under the terms of the Creative Commons Attribution-NoDerivs License, which permits use and distribution in any medium, provided the original work is properly cited and no modifications or adaptations are made.

Reproduction of the images listed below is prohibited and permission must be sought directly from the copyright holder:

Figure 1: (c) EPPO

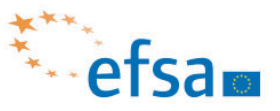

The EFSA Journal is a publication of the European Food Safety Authority, a European agency funded by the European Union.

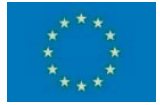




\section{Table of contents}

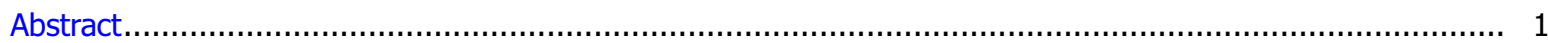

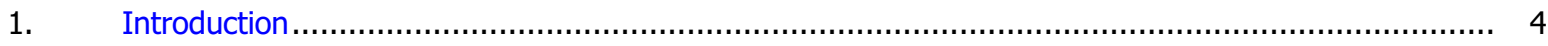

1.1. Background and Terms of Reference as provided by the requestor....................................... 4

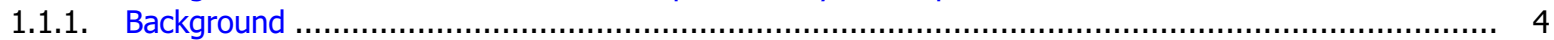

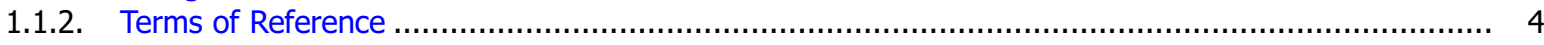

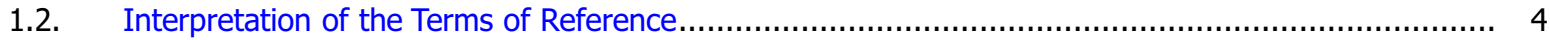

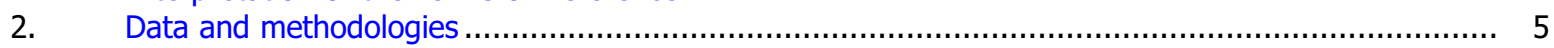

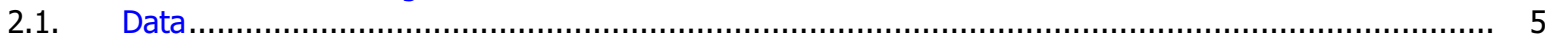

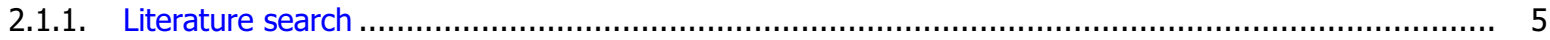

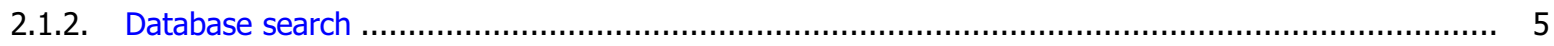

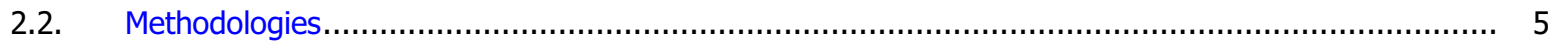

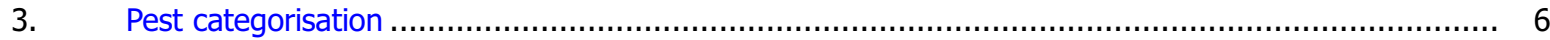

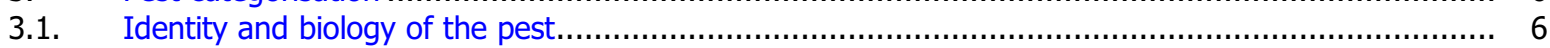

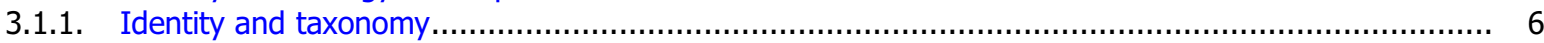

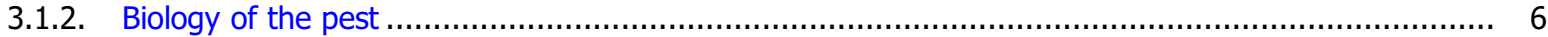

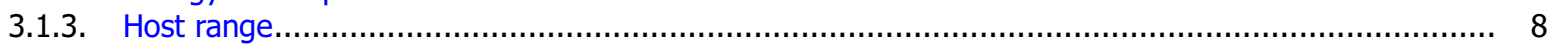

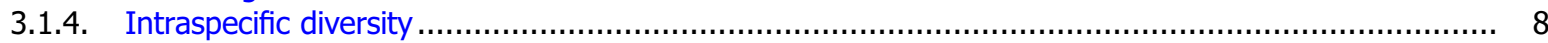

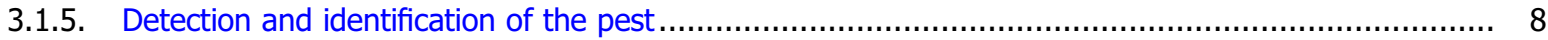

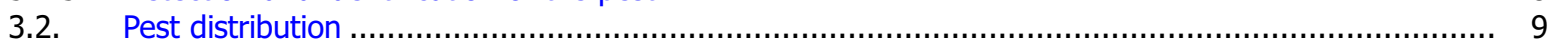

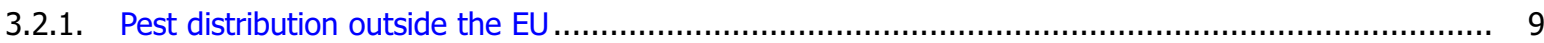

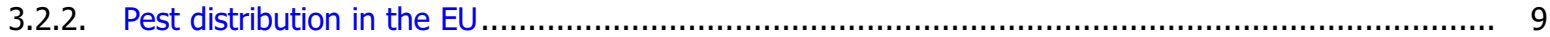

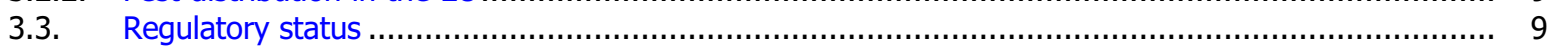

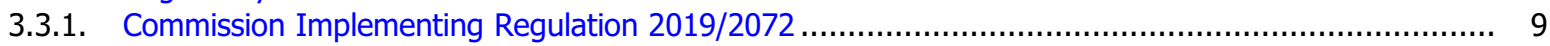

3.3.2. Hosts of Leucinodes orbonalis that are prohibited from entering the Union from third countries ........ 10

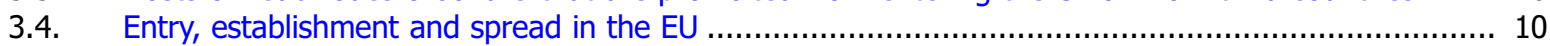

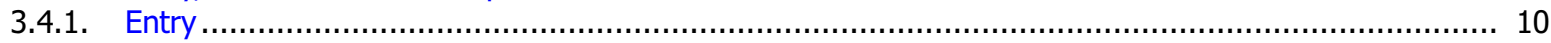

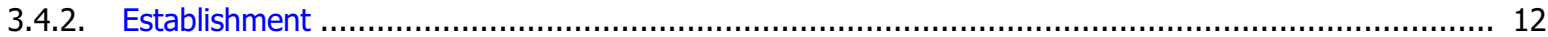

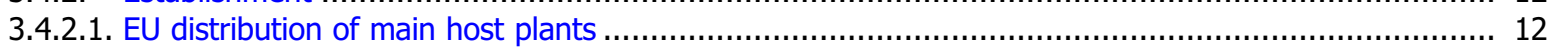

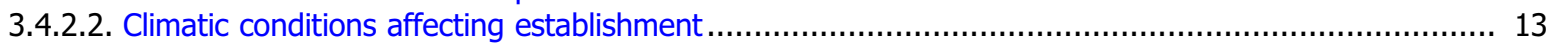

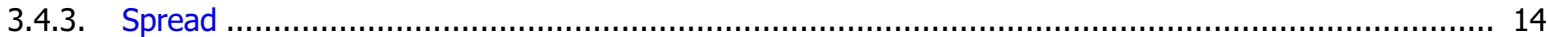

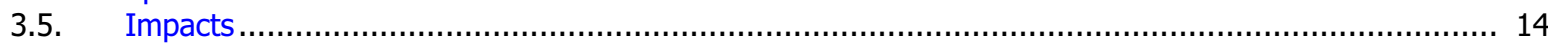

3.6. Available measures and/or potential specific import requirements and limits of mitigation measures.. 15

3.6.1. Identification of potential additional measures ................................................................. 15

3.6.1.1. Biological or technical factors limiting the effectiveness of measures to prevent the entry of the pest 16

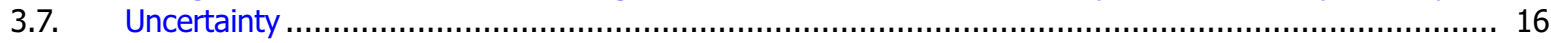

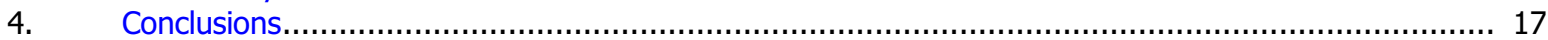

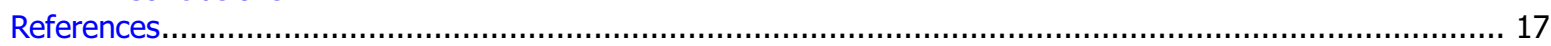

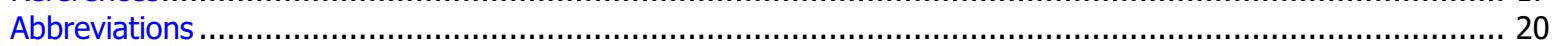

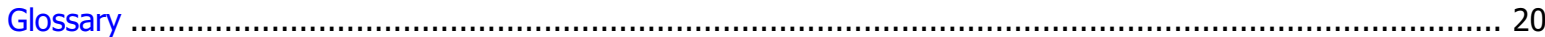

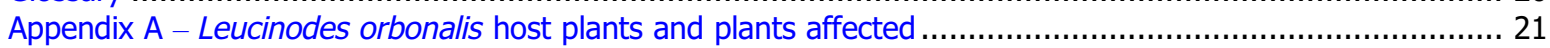

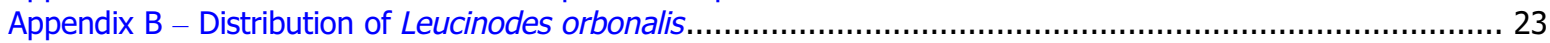

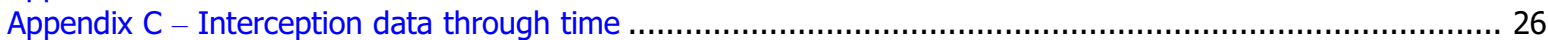

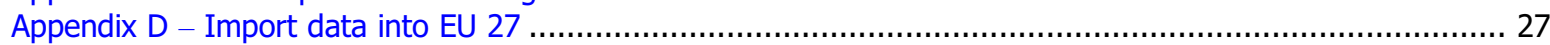




\section{Introduction}

\subsection{Background and Terms of Reference as provided by the requestor}

\subsubsection{Background}

The new Plant Health Regulation (EU) 2016/2031, on the protective measures against pests of plants, is applying from 14 December 2019. A focus on prevention and risk targeting is amongst the primary objectives of this legislation. Furthermore, conditions are laid down in this legislation for plant pests to qualify for listing as Union quarantine pests, protected zone quarantine pests or Union regulated non-quarantine pests. The lists of the EU regulated plant pests together with the associated import or internal movement requirements of commodities are included in Commission Implementing Regulation (EU) 2019/2072.

In line with the principles of the new plant health law, for a proactive approach, the European Commission with the Member States are discussing monthly the reports of the interceptions, together with data from horizon scanning for plant pests of concern of various sources. As outcome of those discussions, a number of plant pests of concern, not regulated in the EU, are identified, for which a risk assessment is needed to decide on potential EU regulation. Leucinodes orbonalis which was recently spilt into two species Leucinodes orbonalis and Leucinodes pseudorbonalis, and Xanthomonas citri pv. viticola are amongst the species identified during these discussions.

In the EU, a number of actions are already in place to mitigate the various multilevel effects of climate change. The aim is to avoid adverse changes to the environment and to ensure food security. As the success of plant pests to establish in an area, depends on various abiotic and biotic parameters, it is anticipated that climate change might affect the risk that certain plant pests pose. Parameters as temperature, humidity, $\mathrm{CO}_{2}$ concentration and salinity of soil affect the survival and pathogenicity of a number of plant pests, as reported in the scientific literature. Changes in temperature, drought and salinity can affect also the geographic distribution of the hosts of plant pests, and as a consequence the plant pests' establishment.

There is therefore a need to develop further the quantitative risk assessment methodology followed for plant pests and consider including the effect of climate change in the assessment of the risk that plant pests pose to the EU.

\subsubsection{Terms of Reference}

In accordance with Article 29(1) of Regulation (EC) No 178/2002, the Commission asks EFSA to develop further the quantitative risk assessment (phase 1 and phase 2) methodology followed for plant pests, to include in the assessments the effect of climate change for plant pests. Such inclusion of climate change scenarios can benefit of the quantitative methodology with comparison of risk assessment scenarios which has been already developed by the EFSA PLH Panel and included in its Guidance on quantitative pest risk assessment. Examples of abiotic parameters affecting the biology of the pests and their hosts' distribution are given in the background. The aim of this methodological development is to enable risk projections in the future, with models taking into account the relevant critical parameters for spread, establishment and potential impact that are affected in a scenario of 'climate change'.

The risk assessments of Leucinodes orbonalis, Leucinodes pseudorbonalis and Xanthomonas citri pv. viticola can be used for the development of the methodology.

\subsection{Interpretation of the Terms of Reference}

EFSA PLH Panel has been requested to conduct a risk assessment for Leucinodes orbonalis. This document is the phase 1 component (pest categorisation) fulfilling the request. The purpose of the pest categorisation is to determine whether $L$. orbonalis fulfils the criteria of a regulated pest for the area of the EU excluding Ceuta, Melilla and the outermost regions of Member States referred to in Article 355(1) of the Treaty on the Functioning of the European Union (TFEU), other than Madeira and the Azores, and so inform European Commission decision-making as to its appropriateness for potential inclusion in the lists of pests of Commission Implementing Regulation (EU) 2019/ 2072.

If $L$. orbonalis fulfils the criteria to be potentially listed as a regulated pest, risk reduction options aimed to prevent entry will be identified. Consideration of climate change is beyond the scope of pest categorisation, but will follow in a separated phase 2 assessment, if $L$. orbonalis satisfies the criteria for quarantine pest $(\mathrm{QP})$ status. 


\section{Data and methodologies}

\subsection{Data}

\subsubsection{Literature search}

A literature search on L. orbonalis was conducted at the beginning of the categorisation in the ISI Web of Science bibliographic database, using the scientific name of the pest as search term. Papers relevant for the pest categorisation were reviewed, and further references and information were obtained from experts, as well as from citations within the references and grey literature.

\subsubsection{Database search}

Pest information, on host(s) and distribution, was retrieved from the European and Mediterranean Plant Protection Organization (EPPO) Global Database (EPPO, online), the CABI databases and scientific literature databases as referred above in section 2.1.1.

Data about the import of commodity types that could potentially provide a pathway for the pest to enter the EU and about the area of hosts grown in the EU were obtained from EUROSTAT (Statistical Office of the European Communities).

The Europhyt and TRACES databases were consulted for pest-specific notifications on interceptions and outbreaks. Europhyt is a web-based network run by the Directorate General for Health and Food Safety (DG SANTÉ) of the European Commission as a subproject of PHYSAN (Phyto-Sanitary Controls) specifically concerned with plant health information. TRACES is the European Commission's multilingual online platform for sanitary and phytosanitary certification required for the importation of animals, animal products, food and feed of non-animal origin and plants into the European Union, and the intra-EU trade and EU exports of animals and certain animal products. Up until May 2020, the Europhyt database managed notifications of interceptions of plants or plant products that do not comply with EU legislation, as well as notifications of plant pests detected in the territory of the Member States and the phytosanitary measures taken to eradicate or avoid their spread. The recording of interceptions switched from Europhyt Interceptions to TRACES in May 2020.

\subsection{Methodologies}

The Panel performed the pest categorisation for $L$. orbonalis, following guiding principles and steps presented in the EFSA guidance on quantitative pest risk assessment (EFSA PLH Panel, 2018), the EFSA guidance on the use of the weight of evidence approach in scientific assessments (EFSA Scientific Committee, 2017) and the International Standards for Phytosanitary Measures No. 11 (FAO, 2013) and No. 21 (FAO, 2004).

The criteria to be considered when categorising a pest as a Union QP is given in Regulation (EU) 2016/2031 Article 3 and Annex 1 to this Regulation. Table 1 presents the Regulation (EU) 2016/2031 pest categorisation criteria on which the Panel bases its conclusions. In judging whether a criterion is met the Panel uses its best professional judgement (EFSA Scientific Committee, 2017) by integrating a range of evidence from a variety of sources (as presented above in Section 2.1) to reach an informed conclusion as to whether or not a criterion is satisfied.

The Panel's conclusions are formulated respecting its remit and particularly with regard to the principle of separation between risk assessment and risk management (EFSA founding regulation (EU) No 178/2002); therefore, instead of determining whether the pest is likely to have an unacceptable impact, deemed to be a risk management decision, the Panel will present a summary of the observed impacts in the areas where the pest occurs, and make a judgement about potential likely impacts in the EU. While the Panel may quote impacts reported from areas where the pest occurs in monetary terms, the Panel will seek to express potential EU impacts in terms of yield and quality losses and not in monetary terms, in agreement with the EFSA guidance on quantitative pest risk assessment (EFSA PLH Panel, 2018). Article 3 (d) of Regulation (EU) 2016/2031 refers to unacceptable social impact as a criterion for QP status. Assessing social impact is outside the remit of the Panel. 
Table 1: Pest categorisation criteria under evaluation, as defined in Regulation (EU) 2016/2031 on protective measures against pests of plants (the number of the relevant sections of the pest categorisation is shown in brackets in the first column)

\section{Criterion of pest categorisation \\ Identity of the pest (Section 3.1) \\ Absence/ presence of the pest in the EU territory (Section 3.2)}

\section{Regulatory status (Section 3.3)}

Pest potential for entry, establishment and spread in the EU territory (Section 3.4)

Potential for consequences in the EU territory (Section 3.5)

Available measures (Specific import requirements) (Section 3.6)

\section{Criterion in Regulation (EU) 2016/2031 regarding} Union quarantine pest (article 3)

Is the identity of the pest established, or has it been shown to produce consistent symptoms and to be transmissible? Is the pest present in the EU territory? If present, is the pest widely distributed within the EU? Describe the pest distribution briefly

If the pest is present in the EU but not widely distributed in the risk assessment area, it should be under official control or expected to be under official control in the near future.

Is the pest able to enter into, become established in, and spread within, the EU territory? If yes, briefly list the pathways Would the pests' introduction have an economic or environmental impact on the EU territory?

Are there measures available to prevent the entry into the EU such that the likelihood of introduction becomes mitigated?

Conclusion of pest categorisation (Section 4) A statement as to whether (1) all criteria assessed by EFSA above for consideration as a potential quarantine pest were met and (2) if not, which one(s) were not met.

\section{Pest categorisation}

\subsection{Identity and biology of the pest}

\subsubsection{Identity and taxonomy}

Is the identity of the pest established, or has it been shown to produce consistent symptoms and/or to be transmissible?

Yes. The identity of the species is established and Leucinodes orbonalis Guenée, 1854 is the accepted name and authority.

Leucinodes orbonalis is an insect in the family Crambidae (Order: Lepidoptera). Pycnarmon discerptalis (Hampson) is a junior synonym (EPPO GD). Its common English name is eggplant shoot and fruit borer or brinjal shoot and fruit borer. The EPPO code $^{1}$ for this species is: LEUIOR (EPPO, online).

The name $L$. orbonalis has been applied to species across Africa and for some interceptions from Africa but taxonomic studies of African Leucinodes indicated that true $L$. orbonalis are restricted to Asia (Hayden et al., 2013; Gilligan and Passoa, 2014; Mally et al., 2015; EFSA, PLH Panel, 2021). This pest categorisation focusses on literature reporting $L$. orbonalis in Asia and Australia.

\subsubsection{Biology of the pest}

Adult females lay eggs singly on the lower surface of young leaves, tender green stems, flower buds, or fruit calyces of hosts, primarily Solanum melongena (Alam et al., 2003). Individual females lay on average approximately 80 to 250 eggs. Most eggs (85\%) are laid on the second night after female emergence although oviposition continues over two or three nights (Mannan et al., 2015a). Eggs usually hatch in 3 to 6 days depending on temperature. Within one hour of hatching larvae bore into the petioles and midribs of large leaves or young growing shoots, buds, flowers or fruit, entering from

\footnotetext{
${ }^{1}$ An EPPO code, formerly known as a Bayer code, is a unique identifier linked to the name of a plant or plant pest important in agriculture and plant protection. Codes are based on genus and species names. However, if a scientific name is changed the EPPO code remains the same. This provides a harmonized system to facilitate the management of plant and pest names in computerized databases, as well as data exchange between IT systems (Griessinger and Roy, 2015; EPPO, 2019).
} 
under the calyx hence leaving no visible sign of infestation (Attygalle et al., 1988; Singh et al., 2019). Soon after boring into the plant, the larvae plug the entrance hole with excreta and remain concealed inside that particular plant part (Alam et al., 2006). Larval feeding creates tunnels within the host.

Regarding $S$. melongena with fruit, female $L$. orbonalis will lay eggs on fruit rather than leaves or stems and so there is a shift from larvae infesting leaves and shoots in young plants to infesting fruits in older plants (Mannan et al., 2015b). For example, in Rajastan (India), shoots are fed upon from early August until late October, peak incidence occurring in late August-early September, while fruits are fed upon from September until November (peak in October) (Choudhary et al., 2018). Further north in the state of West-Bengal, the pest is most active earlier between May and August with peak fruit damage in June (Ghosh and Senapati, 2009).

Multiple larvae can infest individual shoots and fruits. For example, Sultana et al. (2018) reported a mean of 1.1-4.4 larvae per shoot and between 1.3 and 5.0 larvae per fruit, depending on host (S. melongena) variety. There are five larval instars (Mannan et al., 2015a). Larval development takes 12-15 days during the summer and up to 22 days in the winter in South Asia (Alam et al., 2003). The final instar exits the host and drops to pupate on or just below the soil surface (Lal, 1975; Onekutu et al., 2013).

Adults emerge from pupae within 6 to 17 days depending on temperature (Alam et al., 2003). Emergence takes place at night, and $90 \%$ of mating occurs on the first night of adult emergence (Javed et al., 2017). Adult males live for approximately 3-5 days and females for 6-9 days (Mannan et al., 2015a).

In the warmest parts of India where $L$. orbonalis occurs there can be up to ten generations per year (Lall and Ahmad, 1965), further north, in Pakistan, there are five overlapping generations per year (Javed et al., 2017). In West Bengal, where S. melongena is grown year-round, spring-summer crops have higher numbers of $L$. orbonalis than autumn-winter crops (Koundinya et al., 2019). Where there is continuous development and overlapping generations, development from egg to adult takes from 17 to 44 days (Javed et al., 2017).

In the Kullu Valley of Himachal Pradesh (India) at altitudes between 1,200 and 2,000 m, L. orbonalis overwinters from October to April as pupae in the soil, or close to the soil surface, attached to host plants and can survive temperatures of $-6.5^{\circ} \mathrm{C}$ although there is significant mortality (Lal, 1975).

Dhaliwal and Aggarwal (2021) examined the development of $L$. orbonalis under a range of fixed and variable temperatures to estimate minimum temperatures for development $\left(T_{\min }\right)$ and the thermal sum (K) for complete development for life stages and for overall development from egg to adult, estimating $\mathrm{T}_{\min }$ to be $14.6^{\circ} \mathrm{C}$ with $\mathrm{K} 444.3^{\circ}$ + days (DD) (Table 2). Islam et al. (2020) found that a thermal sum of 526.3 DD was necessary for development of female $L$. orbonalis from egg to adult; such a figure is within the ranges provided by Dhaliwal and Aggarwal (2021) (Table 2).

Table 2: Important features of the life history strategy of Leucinodes orbonalis

\begin{tabular}{|c|c|c|}
\hline $\begin{array}{l}\text { Life } \\
\text { stage }\end{array}$ & Phenology and relation to host & $\begin{array}{l}\text { Minimum and maximum thresholds for } \\
\text { development }\left(T_{\min }\right) \text { and thermal sum }(K) \\
\text { degree days from a variety of linear and } \\
\text { non-linear development models reported } \\
\text { by Dhaliwal and Aggarwal ( } 2021)\end{array}$ \\
\hline Egg & $\begin{array}{l}\text { Laid individually on leaves, stem, shoots and fruit, } \\
\text { potentially all year round where there is overlapping } \\
\text { generations. }\end{array}$ & $\begin{array}{l}\text { Estimated } \mathrm{T}_{\min } 8.9 \text { to } 9.5^{\circ} \mathrm{C} \\
\mathrm{K} 68.9 \text { to } 74.5 \mathrm{DD}\end{array}$ \\
\hline Larva & $\begin{array}{l}\text { Burrows into host and feeds internally. Entry hole } \\
\text { blocked and difficult to detect. Can be found all year } \\
\text { round where there is overlapping generations. }\end{array}$ & $\begin{array}{l}\text { Estimated } \mathrm{T}_{\min } 8.1 \text { to } 9.5^{\circ} \mathrm{C} \\
\text { Estimated K } 253.8 \text { to } 280.5 \mathrm{DD}\end{array}$ \\
\hline Pupa & $\begin{array}{l}\text { Soil surface or just below the soil, can be attached } \\
\text { to host plant. Pupae can overwinter. }\end{array}$ & $\begin{array}{l}\text { Estimated } T_{\min } 10.7 \text { to } 14.0^{\circ} \mathrm{C} \\
\text { Estimated } \mathrm{K} 136.8 \text { to } 164.5 \mathrm{DD}\end{array}$ \\
\hline Adult & $\begin{array}{l}\text { Emerges at night, mates and lives for approximately } \\
3 \text { to } 9 \text { days. }\end{array}$ & $\begin{array}{l}\text { Estimated } T_{\min } \text { egg to adult } 11.6 \text { to } 14.6^{\circ} \mathrm{C} \\
\text { Estimated } \mathrm{K} \text { egg to adult } 444.3 \text { to } 530.7 \mathrm{DD}\end{array}$ \\
\hline
\end{tabular}




\subsubsection{Host range}

Most literature focuses on eggplant, S. melongena, as the principal host. EPPO (GD) categorises S. melongena and $S$. aethiopicum as major hosts. Although $L$. orbonalis can develop on both potato and tomato plants, it is not commonly reported as a pest of these crops. Boopal et al. (2013) and Mannan et al. (2015a) successfully reared $L$. orbonalis larvae in the laboratory with larvae feeding on peeled potato tubers. Boopal et al. (2013) also raised larvae to adulthood with larvae developing in tomato fruit in laboratory conditions. Maureal et al. (1982) reported that 'even when tomato was planted in the immediate vicinity of eggplant [in the field], the borer was never observed to infest tomato fruits unless when subjected to hunger stress'. Hayden et al. (2013) notes that the stalks of potato are fed upon by larvae rather than potato tubers.

Alam et al. (2003) consider L. orbonalis as virtually monophagous, feeding principally on S. melongena; however, they recognise that tomato (S. lycopersicum) and potato ( $S$. tuberosum) as well as the nightshades $S$. nigrum and $S$. indicum and turkey berry (S. torvum) have been reported as hosts. Lall and Ahmad (1965) report that $L$. orbonalis feeds on solanaceous weeds such as $S$. nigrum and S. xanthocarpum (=S. virginianum) when its preferred host, S. melongena, is not available. Note that all hosts reported by Alam et al. (2003) are Solanaceae. However, EPPO GD provides a more extensive list of hosts, including some which are not within the Solanaceae. Appendix A provides a list of host plants and plants reported as affected by L. orbonalis, as well as plants on which interceptions have occurred.

\subsubsection{Intraspecific diversity}

There are no reports of intraspecific variation within $L$. orbonalis.

\subsubsection{Detection and identification of the pest}

Are detection and identification methods available for the pest?

Yes, methods for detection and morphological and molecular methods for identification are available.

\section{Symptoms}

Larval feeding in stems inhibits the translocation of nutrients towards shoots causing infested plants to wither and droop; the growth of the plant and size and number of fruits can be significantly reduced (Latif et al., 2010). Larval feeding inside shoots results in progressive wilting of the young shoot resulting in a characteristic symptom called 'dead heart' (Alam et al., 2006). Feeding damage to the fruit is not always visible; if infested fruit are cut open larvae can be seen in tunnels. Exit holes in fruit can be seen when larvae have abandoned the fruit to pupate in the soil.

\section{Detection}

A variety of trap designs can be used to detect flying adults (Cork et al., 2003) and pheromone lures are available (Alam et al., 2003).

A key for the identification of microlepidoptera on Solanaceae by Hayden et al. (2013) is available online.

\section{Description}

A detailed description of the larva and adults is provided in Hayden et al. (2013) and by Mally et al. (2015).

Egg: flattened, elliptical, $0.5 \mathrm{~mm}$ diameter; creamy-white when laid changes to red before hatching (Alam et al., 2003).

Larva: Pink, covered with sparsely distributed hairs all over the body. Fully grown larva about 20 mm long (Hayden et al., 2013; Mally et al., 2015; Javed et al., 2017)

Pupa: white or beige becoming dark brown, oval (Mally et al., 2015).

Adult: white with pale brown or black spots at the back of the thorax and abdomen; wings are white with a pinkish or bluish tinge and are ringed with small hairs along the apical and anal margins; forewings have several black pale and light brown spots. 20-22 mm wingspan (Mally et al., 2015; Alam et al., 2003). 


\subsection{Pest distribution}

\subsubsection{Pest distribution outside the EU}

L. orbonalis is a tropical and subtropical species native to Asia and Australia (Figure 1) with India thought to be its centre of origin (Karthika et al., 2019). Until Hayden et al. (2013) and Gilligan and Passoa (2014) reported that $L$. orbonalis was restricted to Asia, it was thought that $L$. orbonalis also occurred in sub-Saharan Africa. Literature previously reporting $L$. orbonalis from Africa should be regarded as referring to members of a complex of other species of Leucinodes native to Africa and not as referring to L. orbonalis (Mally et al., 2015; EFSA PLH Panel, 2021). Appendix A lists the global distribution based on EPPO Global Database.

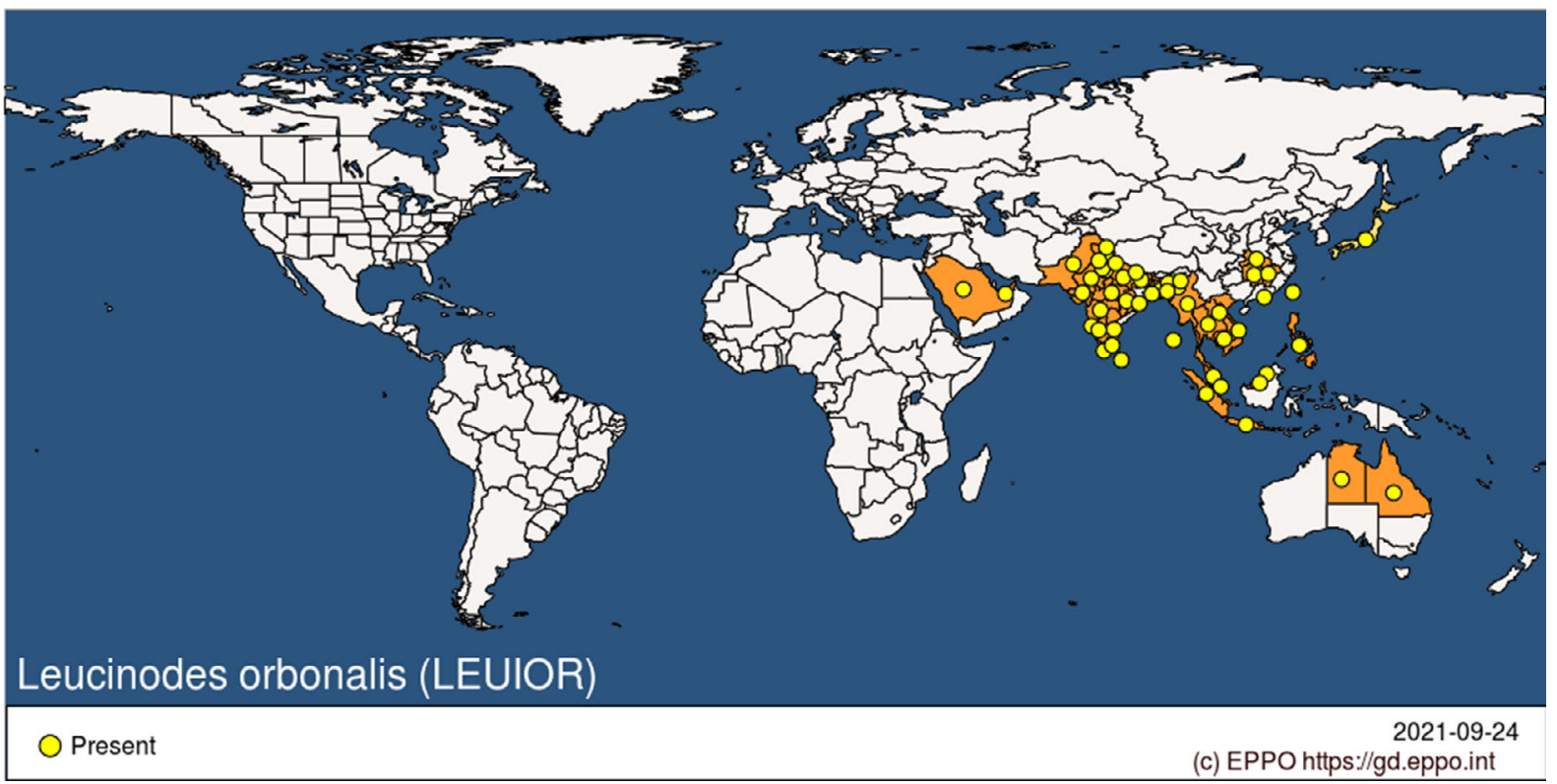

Figure 1: Global distribution of Leucinodes orbonalis (Source: EPPO Global Database accessed on 24/9/21)

\subsubsection{Pest distribution in the EU}

Is the pest present in the EU territory? If present, is the pest widely distributed within the EU?

No, L. orbonalis is not present in the EU.

\subsection{Regulatory status}

\subsubsection{Commission Implementing Regulation 2019/2072}

Leucinodes orbonalis is not listed in Annex II of Commission Implementing Regulation (EU) 2019/ 2072, an implementing act of Regulation (EU) 2016/2031. 


\subsubsection{Hosts of Leucinodes orbonalis that are prohibited from entering the Union from third countries}

Table 3: List of plants, plant products and other objects that are Leucinodes orbonalis hosts whose introduction into the Union from certain third countries is prohibited (Source: Commission Implementing Regulation (EU) 2019/2072, Annex VI)

\begin{tabular}{|c|c|c|c|}
\hline & Description & CN Code & $\begin{array}{l}\text { Third country, group of third } \\
\text { countries or specific area of third } \\
\text { country }\end{array}$ \\
\hline 15. & $\begin{array}{l}\text { Tubers of Solanum tuberosum, } \\
\text { seed potatoes }\end{array}$ & 07011000 & Third countries other than Switzerland \\
\hline 16. & $\begin{array}{l}\text { Plants for planting of stolon- or } \\
\text { tuber-forming species of } \\
\text { Solanum L. }\end{array}$ & $\begin{array}{l}\text { ex } 06011090 \text { ex } 06012090 \\
\text { ex } 06029050 \text { ex } 06029070 \\
\text { ex } 06029091 \text { ex } 06029099\end{array}$ & Third countries other than Switzerland \\
\hline 17. & $\begin{array}{l}\text { Tubers of species of Solanum } \\
\text { L., and their hybrids, other } \\
\text { than those specified in entries } \\
15 \text { and } 16\end{array}$ & $\begin{array}{l}\text { ex } 06011090 \text { ex } 06012090 \\
07019010070190500701 \\
9090\end{array}$ & Third countries other than $[\ldots]$ \\
\hline 18. & $\begin{array}{l}\text { Plants for planting of } \\
\text { Solanaceae other than seeds } \\
\text { and the plants covered by } \\
\text { entries } 15,16 \text { or } 17 .\end{array}$ & $\begin{array}{l}\text { ex } 06029030 \text { ex } 06029045 \\
\text { ex } 06029046 \text { ex } 06029048 \\
\text { ex } 06029050 \text { ex } 06029070 \\
\text { ex } 06029091 \text { ex } 06029099\end{array}$ & Third countries other than $[\ldots]$ \\
\hline 19. & $\begin{array}{l}\text { Soil as such consisting in part } \\
\text { of solid organic substances }\end{array}$ & $\begin{array}{l}\text { ex } 25309000 \\
\text { ex } 38249993\end{array}$ & Third countries other than Switzerland \\
\hline
\end{tabular}

Note that potato tubers are only known as experimental hosts. In nature larvae feed and develop on above ground parts of $S$. tuberosum.

\subsection{Entry, establishment and spread in the EU}

\subsubsection{Entry}

Is the pest able to enter into the EU territory? If yes, identify and list the pathways.

Yes, $L$. orbonalis has been intercepted entering the EU 350 times from a range of Asian countries on a range of produce.

Comment on plants for planting as a pathway.

In principle, larvae could enter the EU on plants for planting given that eggs could be on leaves and larvae in stems and shoots; however, as Solanaceae from countries other than those in the Euro-Mediterranean area are prohibited entry into the EU, and $L$. orbonalis does not occur in the Euro-Mediterranean area, such pathways do not currently exist. There are no records of plants for planting being intercepted with $L$. orbonalis.

Regarding plants for planting as a pathway for spread within the EU; eggs could be carried on leaves and larvae in stems or shoots of host plants, especially $S$. melongena.

Table 4 lists potential pathways for the entry of $L$. orbonalis into the EU. 
Table 4: $\quad$ Potential pathways for Leucinodes orbonalis into the EU 27

\begin{tabular}{|c|c|c|}
\hline $\begin{array}{l}\text { Pathways } \\
\text { Description (e.g. } \\
\text { host/intended } \\
\text { use/source) }\end{array}$ & Life stage & $\begin{array}{l}\text { Relevant mitigations [e.g. prohibitions (Annex VI) } \\
\text { or special requirements (Annex VII) within } \\
\text { Implementing Regulation 2019/2072] }\end{array}$ \\
\hline $\begin{array}{l}\text { Growing plants for } \\
\text { planting of Solanum } \\
\text { melongena and other } \\
\text { Solanaceae, excluding } \\
\text { seed }\end{array}$ & $\begin{array}{l}\text { Eggs on leaves or stems, } \\
\text { Larvae in leaves or stems, } \\
\text { Pupae in soil could be } \\
\text { attached to roots }\end{array}$ & $\begin{array}{l}\text { Annex VI (18.) bans the introduction of plants for planting } \\
\text { of Solanaceae other than seeds }\end{array}$ \\
\hline $\begin{array}{l}\text { Fresh produce, } \\
\text { especially Solanum } \\
\text { melongena and other } \\
\text { Solanaceae }\end{array}$ & Larvae in fruits & $\begin{array}{l}\text { Annex VII }(68,69 \text { and } 70) \text { require statements that fruits } \\
\text { are free from specified quarantine pests } \\
\text { (Neoleucinodes elegantalis, Thrips palmi and } \\
\text { Keiferia lycopersicella) }\end{array}$ \\
\hline Soil/growing media & Pupa & $\begin{array}{l}\text { Annex VI (19. \& 20.) bans the introduction of soil and } \\
\text { growing media as such into the Union from third countries } \\
\text { other than Switzerland }\end{array}$ \\
\hline Soil on machinery & Pupa & $\begin{array}{l}\text { Annex VII (2.) Official statement that machinery or } \\
\text { vehicles are cleaned and free from soil and plant debris }\end{array}$ \\
\hline
\end{tabular}

Notifications of interceptions of harmful organisms began to be compiled in Europhyt in May 1994 and in TRACES in May 2020. As at June 2021, there were 350 records of interceptions of $L$. orbonalis from Asian countries and nine interceptions of unspecified Leucinodes sp. in the Europhyt and TRACES databases (Appendix C). $92.8 \%$ of interceptions occur on Solanum species, the majority on $S$. melongena (Table 5). Interceptions on non-solanaceous plant material (7.2\% of interceptions) may indicate hitchhiking rather than occurrence of the pest on true hosts. Records in TRACES and Europhyt of $L$. orbonalis from African countries are assumed to be interceptions of $L$. pseudorbonalis or other Leucinodes species (EFSA PLH Panel, 2021).

Table 5: $\quad$ Interceptions of Leucinodes orbonalis and Leucinodes sp. ${ }^{(1)}$ from Asian countries

\begin{tabular}{|c|c|c|c|c|c|c|c|c|c|c|c|}
\hline & 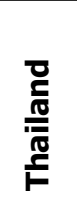 & 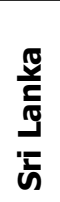 & 疍 & $\frac{\frac{\pi}{5}}{\frac{\pi}{\pi}}$ & $\begin{array}{l}\frac{\mathbb{0}}{8} \\
\frac{0}{8} \\
\text { ह }\end{array}$ & 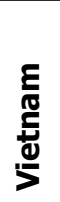 & 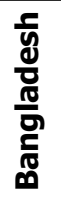 & 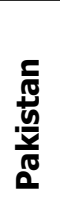 & ஜூ & 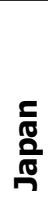 & $\underline{\xi}$ \\
\hline Solanum melongena & 96 & 35 & 35 & 29 & 11 & 9 & 13 & 9 & 5 & - & 242 \\
\hline Solanum torvum & 33 & 11 & - & - & 3 & 3 & - & - & 2 & - & 52 \\
\hline Other Solanum spp. ${ }^{(2)}$ & 8 & 24 & 2 & - & - & 3 & - & 1 & 1 & - & 39 \\
\hline Mangifera sp. & - & 3 & 2 & - & - & - & - & - & - & - & 5 \\
\hline Momordica sp. & 1 & 2 & 1 & - & - & - & - & 1 & - & - & 5 \\
\hline Ocimum sp. & 4 & - & - & - & - & - & - & - & - & - & 4 \\
\hline Citrus hystrix & 3 & - & - & - & - & - & - & - & - & - & 3 \\
\hline Psidium guajava & - & - & 2 & - & 1 & - & - & - & - & - & 3 \\
\hline Capsicum annuum & - & - & - & - & - & - & - & - & - & 1 & 1 \\
\hline Ipomoea aquatica & - & 1 & - & - & - & - & - & - & - & - & 1 \\
\hline Murraya paniculata & - & 1 & - & - & - & - & - & - & - & - & 1 \\
\hline Spondias dulcis & - & 1 & - & - & - & - & - & - & - & - & 1 \\
\hline Vigna sp. & - & 1 & - & - & - & - & - & - & - & - & 1 \\
\hline Unspecified & - & - & 1 & - & - & - & - & - & - & - & 1 \\
\hline Sum & 145 & 79 & 43 & 29 & 15 & 15 & 13 & 11 & 8 & 1 & 359 \\
\hline
\end{tabular}

(1): Includes 9 Leucinodes not identified to species on S. melongena (ex. Sri Lanka $\times 3$, ex Cambodia $\times 2$, ex India $\times 1$; on S. torvum ex Thailand $\times 1$, on unspecified Solanum species ex Sri Lanka $\times 1$, ex Vietnam $\times 1$ ).

(2): Other Solanum species includes S. aculeatissimum, S. aethiopicum, S. anguivi, S. stramoniifolium, S. undatum, S. virginianum and unspecified species. 
Table 5 shows that most interceptions have been recorded from $S$. melongena. However, there are limits regarding how interception data can be interpreted. A more meaningful analysis would be possible if the total number of consignments imported and inspected were available. Reports of interception should therefore be interpreted with caution if seeking to identify pathways most likely to carry particular pests (MacLeod, 2015).

Table 6 shows EU 27 annual imports of S. melongena from countries where L. orbonalis occurs.

Table 6: EU 27 annual imports of Solanum melongena (eggplant) from countries where Leucinodes orbonalis occurs (hundreds of $\mathrm{kg}$ ) Source: Eurostat. Countries from which interceptions on S. melongena have occurred are marked $\left.{ }^{*}\right)$

\begin{tabular}{l|c|c|c|c|c|c}
\hline & $\mathbf{2 0 1 6}$ & $\mathbf{2 0 1 7}$ & $\mathbf{2 0 1 8}$ & $\mathbf{2 0 1 9}$ & $\mathbf{2 0 2 0}$ & 5-year mean \\
\hline Laos* & 623.61 & 507.16 & 553.87 & 651.54 & 575.33 & 582.30 \\
\hline Thailand* & 371.71 & 361.70 & 392.81 & 482.10 & 435.44 & 408.75 \\
\hline Vietnam* & 439.72 & 375.63 & 338.35 & 307.70 & 38.43 & 299.97 \\
\hline Malaysia* & 319.24 & 368.87 & 253.99 & 213.25 & 7.29 & 232.53 \\
\hline Cambodia* & 6.81 & 10.77 & 13.77 & 37.58 & 140.51 & 41.89 \\
\hline Sri Lanka* & 10.30 & 6.57 & 0.35 & 23.51 & 15.29 & 11.20 \\
\hline India* & 13.83 & 4.45 & - & 15.61 & 3.25 & 7.43 \\
\hline Pakistan* & 0.40 & 0 & 3.85 & 0.48 & 10.60 & 3.07 \\
\hline Indonesia & - & 0 & 0.21 & 2.93 & 10.35 & 2.70 \\
\hline Japan* & 0.24 & 1.24 & 0.53 & 1.94 & 0.38 & 0.87 \\
\hline Bangladesh* & 0.15 & 1.05 & - & - & - & 0.24 \\
\hline Philippines & - & 0 & - & 0.86 & - & 0.17 \\
\hline China & - & 0 & - & 0.60 & - & 0.12 \\
\hline United Arab Emirates & - & 0 & - & 0.10 & - & 0.02 \\
\hline Australia & - & 0 & - & - & - & 0 \\
\hline Singapore & - & 0 & - & - & - & 0 \\
\hline Taiwan & - & 0 & - & - & - & 0 \\
\hline
\end{tabular}

Appendix D provides EU 27 import data for some other $L$. orbonalis hosts.

\subsubsection{Establishment}

Is the pest able to become established in the EU territory?

Yes, biotic factors (host availability) and abiotic factors (climate suitability) suggest that some areas of the EU would be suitable for establishment. However, the lack of EU outbreaks despite 350 previous interceptions suggests there is uncertainty around the ability of $L$. orbonalis to transfer to a host after arrival in the EU.

The warmest southern areas of the EU around the Mediterranean where there are very few days of frost each year and where hosts are grown both outdoors and in protected conditions would provide areas where establishment is most suitable; such areas could include parts of Cyprus, southern Greece, and southern Italy, Malta, southern Portugal and parts of coastal eastern Spain.

Climatic mapping is the principal method for identifying areas that could provide suitable conditions for the establishment of a pest taking key abiotic factors into account (Baker, 2002). Availability of hosts is considered in Section 3.4.2.1. Climatic factors are considered in Section 3.4.2.2.

\subsubsection{EU distribution of main host plants}

While $L$. orbonalis is primarily regarded as a pest of $S$. melongena, it can feed on a number of crops and wild plants that grow in the EU (Table 7). In the EU S. melongena production is concentrated in Mediterranean countries and Romania, where it is produced both outdoors and indoors. 
Table 7: Harvested area of some Leucinodes orbonalis hosts in EU 27, 2016-2020 (thousand ha). Source EUROSTAT (accessed 19/7/2021)

\begin{tabular}{l|l|r|r|r|r|r}
\hline Crop & Code & \multicolumn{1}{|c|}{$\mathbf{2 0 1 6}$} & \multicolumn{1}{|c|}{$\mathbf{2 0 1 7}$} & \multicolumn{1}{|c|}{$\mathbf{2 0 1 8}$} & \multicolumn{1}{c|}{$\mathbf{2 0 1 9}$} & \multicolumn{1}{c}{$\mathbf{2 0 2 0}$} \\
\hline Potatoes (including seed potatoes) & R1000 & $1,550.51$ & $1,601.18$ & $1,562.85$ & $1,607.36$ & $1,660.31$ \\
\hline Field peas & P1100 & 861.1 & 985.79 & 829.14 & 785.58 & 828.85 \\
\hline Tomatoes & V3100 & 246.80 & 240.87 & 239.55 & 235.14 & 236.46 \\
\hline Fresh peas & V5100 & 142.53 & 141.93 & 143.95 & $:$ & 150.44 \\
\hline Peppers (Capsicum) & V3600 & 57.59 & 57.47 & 56.27 & 59.68 & 59.66 \\
\hline Eggplants & V3410 & 21.58 & 20.73 & 21.44 & 20.63 & 21.36 \\
\hline Beetroot & V4300 & 23.38 & 23.51 & 24.25 & 25.12 & 24.88 \\
\hline
\end{tabular}

$\because$ ' data not available.

Recognising that tomatoes and peppers are also hosts, and that $L$. orbonalis is a warmth loving organism, the EU27 area of production of tomatoes and peppers grown in greenhouses is shown in Table 8.

Table 8: Harvested area of greenhouse production for tomatoes and peppers, Leucinodes orbonalis hosts, in EU 27, 2016-2020 (thousand ha). Source EUROSTAT (accessed 13/8/2021)

\begin{tabular}{l|l|l|l|l|l|l}
\hline Crop & Code & $\mathbf{2 0 1 6}$ & $\mathbf{2 0 1 7}$ & $\mathbf{2 0 1 8}$ & $\mathbf{2 0 1 9}$ & $\mathbf{2 0 2 0}$ \\
\hline Tomatoes & V3100s & 41.97 & 40.90 & 41.72 & 39.48 & 39.00 \\
\hline Peppers (Capsicum) & V3600s & 20.04 & 20.90 & 20.90 & 22.14 & 22.99 \\
\hline
\end{tabular}

\subsubsection{Climatic conditions affecting establishment}

L. orbonalis is a pest found in tropical and subtropical countries in Asia; it is also found in Australia (Northern Territories and Queensland). Some climate types that occur in the EU are also found in tropical and sub-tropical countries where L. orbonalis occurs, for example Bsh, Bsk, Cfa and Csa (Figure 2). These climates are represented by approximately $18 \%$ of EU 27 five arcmin grid cells (MacLeod and Korycinska, 2018).

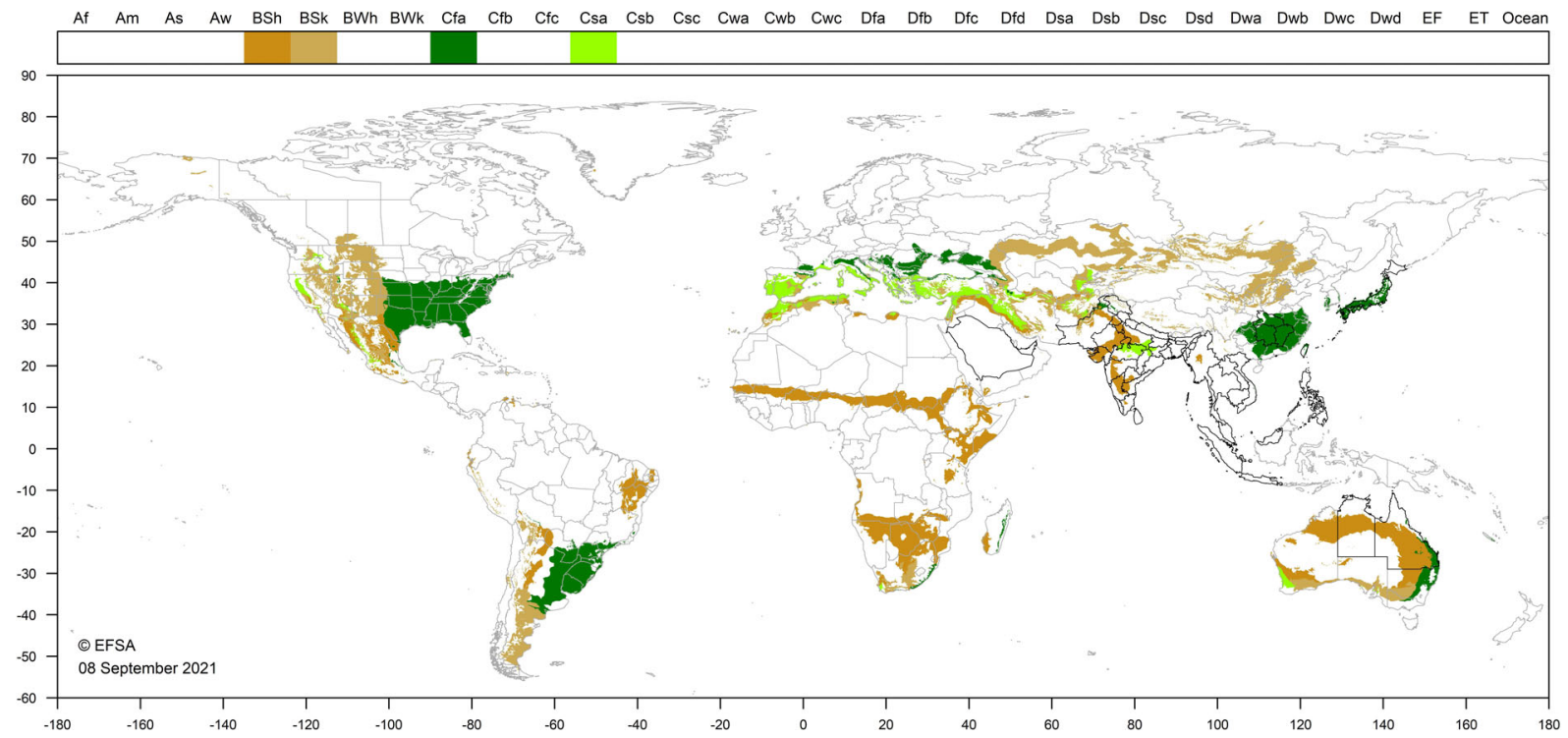

Figure 2: World distribution of four Köppen-Geiger climate types that occur in the EU and which occur in countries where Leucinodes orbonalis has been reported. (Countries where $L$. orbonalis occur are highlighted with black borders)

Numerous studies have examined the thermal biology of $L$. orbonalis and appear to draw a similar conclusion: that $L$. orbonalis is a warmth loving organism. Katiyar and Mukharji (1974) report that in the laboratory egg development was severely delayed at $15^{\circ} \mathrm{C}$, with only one egg batch out of 15 hatching; development was fastest between $20^{\circ} \mathrm{C}$ and $25^{\circ} \mathrm{C}$. Pupae held at $10^{\circ} \mathrm{C}$ did not develop. 
Singh and Singh (2003) found that the highest levels of fecundity occurred when the average minimum temperature was more than $17^{\circ} \mathrm{C}$ and the average maximum temperature more than $27^{\circ} \mathrm{C}$ with average relative humidity more than $85 \%$. Dhaliwal and Aggarwal (2021) estimate the threshold temperature for development from egg to adult to be $14.6^{\circ} \mathrm{C}$. Mall et al. (1992) report that $30^{\circ} \mathrm{C}$ and $70-90 \%$ RH were the most favourable conditions for L. orbonalis population growth in the field.

Although detailed studies on the thermal biology of $L$. orbonalis indicate a relatively high temperature threshold is required for complete development (approx. $15^{\circ} \mathrm{C}$ (Dhaliwal and Aggarwal, 2021)), Lal (1975) reports some $L$. orbonalis surviving as overwintering pupae at altitudes between 1,200 and $2,000 \mathrm{~m}$ where temperatures drop to $-6.5^{\circ} \mathrm{C}$ during winter months although there is significant pupal mortality. Populations at such altitudes therefore appear to enter a diapause to survive unsuitable conditions whereas populations at lower altitudes are not reported to diapause and are found all year round. This gives rise to uncertainty as to the extent of potential establishment of $L$. orbonalis outdoors in the EU which may vary according to where $L$. orbonalis originates. i.e. $L$. orbonalis which can overwinter and survive $-6.5{ }^{\circ} \mathrm{C}$ could potentially establish more widely in the EU than $L$. orbonalis which do not.

L. orbonalis does not appear to be a pest in greenhouses (van der Gaag and Stigter, 2005). However, should there be an introduction to a protected crop, it is possible that a population could develop. Temperatures in Dutch greenhouses growing S. melongena are usually between $20^{\circ} \mathrm{C}$ and $25^{\circ} \mathrm{C}$ and may exceed $30^{\circ} \mathrm{C}$ during warm periods (van der Gaag and Stigter, 2005). Such temperatures exceed the minimum required for development of $L$. orbonalis although whether populations would persist into the foreseeable future within glasshouses is uncertain given the careful management practices employed.

\subsubsection{Spread}

Describe how the pest would be able to spread within the EU territory following establishment?

Adult $L$. orbonalis can fly and could spread within the EU. They are not known to be migratory.

Comment on plants for planting as a mechanism of spread.

Regarding plants for planting as a pathway for spread within the EU; eggs could be carried on leaves and larvae in stems or shoots of host plants, especially $S$. melongena.

L. orbonalis is a free-living organism and adults can fly. Some Crambidae are known to be strongly migratory and can sustain long flights over bodies of water, e.g. Cnaphalocrocis medinalis (Fu et al., 2014). Unfortunately, no information on the dispersal ability of adult $L$. orbonalis could be found. If $L$. orbonalis was a migratory species reports of such behaviour should have been evident within the literature given the economic importance of $L$. orbonalis in Asia. Recognising that no evidence for migration was found, the Panel assumes that $L$. orbonalis is not a migratory species. Nevertheless, adults would be expected to disperse during night flights, perhaps flying hundreds or even thousands of meters. For comparison, adult female European corn borer, Ostrinia nubilalis, also a member of the Crambidae, have been measured flying $3.1 \mathrm{~km}$ during a single flight in laboratory studies (Dorhout et al., 2008).

\subsection{Impacts}

Would the pests' introduction have an economic or environmental impact on the EU territory?

Yes, the introduction of $L$. orbonalis into the EU would have an economic impact, most likely on S. melongena production.

L. orbonalis is thought to be the most serious pest of $S$. melongena in Asia and is a limiting factor to its production (Ahmad et al., 2018; Akter et al., 2018). Early generations of L. orbonalis that feed on the leaves or developing shoots of $S$. melongena can cause leaves to drop; larval feeding inside shoots results in wilting of the young shoots. The damaged shoots ultimately drop off, resulting in fewer flowers and so loss of fruit, lowering yield. While new shoots may grow the resulting fruit will be smaller (Hossain et al., 2013; Baidoo et al., 2018). Later generations whose larvae burrow into fruit 
make them unsuitable for consumption (Attygalle et al., 1988) and prevent the fruit from being marketed resulting in economic yield loss (Alam et al., 2003, 2006; Mainali, 2014; Singh et al., 2019). Larval burrowing into $S$. melongena provides access for pathogens and secondary infection by bacteria causing rotting of fruits and further deteriorates the quality of fruits (Javed et al., 2017).

Estimates of loss or damage caused by L. orbonalis vary considerably. Mall et al. (1992) reported average yield losses of $13 \%$ (consisting of 8 to $111 \mathrm{~kg} / \mathrm{ha}$ lost if the unconsumable part of the fruit was removed and the reminder of the fruit was kept, up to 46 to $380 \mathrm{~kg} / \mathrm{ha}$ if all fruit with any damage was rejected); Mehto et al. (1983) reported yield reductions ranging from $50 \%$ to $60 \%$ and Patnaik (2000) reported that damage to fruit ranges from $48 \%$ to $86 \%$.

High relative humidity and heavy rainfall favour outbreaks of $L$. orbonalis hence there is greater abundance of $L$. orbonalis during the monsoon season (Ghosh and Senapati, 2009).

Although $L$. orbonalis is a serious pest of $S$. melongena in tropical and sub-tropical Asia with most impact occurring during the monsoon season, such conditions do not occur in the EU. Whilst feeding damage would cause losses in production, the magnitude of losses in the EU is not expected be as high as in Asia.

Natikar and Balikai (2018) reported that $L$. orbonalis had become the most destructive pest of potatoes (S. tuberosum) in Karnataka (southern India) causing heavy yield losses in recent years. Surveys within 20 villages during 2016/17 revealed up to $22.3 \%$ of shoots were infested during the vegetative growing stage.

No reports of $L$. orbonalis damage to crops in Queensland and Northern Territory (Australia) were found during the preparation of this pest categorisation. The lack of reports from Australia, where growing conditions could be more similar to southern and Mediterranean Europe might indicate that L. orbonalis does not cause noticeable impact. Biotic factors (e.g. presence of natural enemies) could also be responsible for lowering impacts in Australia.

\subsection{Available measures and/or potential specific import requirements and limits of mitigation measures}

Are there measures available to prevent the entry into the EU (and spread for pests already present) such that the risk becomes mitigated?

Yes, solanaceous plants for planting (other than seed) are prohibited from entering the EU from third countries (Section 3.3.2). Host produce such as $S$. melongena fruit require a phytosanitary certificate so must be inspected prior to export. If $L$. orbonalis were listed as an EU QP, consignments could not be exported to the EU if $L$. orbonalis was detected. Fruit could be sourced from areas free of $L$. orbonalis (see Section 3.6.1).

\subsubsection{Identification of potential additional measures}

Phytosanitary measures (prohibitions) are currently applied to some host plants for planting (see Section 3.3.2).

Potential control measures on hosts that are imported are listed in Table 9. 
Table 9: Selected control measures (a full list is available in EFSA PLH Panel, 2018) for pest entry (and spread when applicable) in relation to currently unregulated hosts and pathways

\begin{tabular}{|c|c|}
\hline $\begin{array}{l}\text { Special requirements summary } \\
\text { (with hyperlink to information } \\
\text { sheet if available) }\end{array}$ & Potential control measure summary \\
\hline Pest freedom & $\begin{array}{l}\text { Used to mitigate likelihood of infestation by specified pest at origin, hence } \\
\text { to mitigate entry. } \\
\text { Host produce should be free of } L \text {. orbonalis. }\end{array}$ \\
\hline Managed growing conditions & $\begin{array}{l}\text { Cultural practices, including crop rotation, solarisation, or sanitation could be } \\
\text { used to reduce field densities of } \\
\text { L. orbonalis. Used to mitigate likelihood of infestation at origin }\end{array}$ \\
\hline Growing plants in isolation & $\begin{array}{l}\text { Used to mitigate likelihood of infestation by specified pest in vicinity of } \\
\text { growing site } \\
\text { Growing hosts under protective netting or similar to prevent infestation } \\
\text { would help. }\end{array}$ \\
\hline $\begin{array}{l}\text { Certification of reproductive material } \\
\text { (voluntary/official) }\end{array}$ & Used to mitigate pests that are included in a certification scheme \\
\hline $\begin{array}{l}\text { Chemical treatments on crops } \\
\text { including reproductive material }\end{array}$ & $\begin{array}{l}\text { Used to mitigate likelihood of infestation of pests susceptible to chemical } \\
\text { treatments - chemicals already widely used resulting in development of } \\
\text { pesticide resistance. }\end{array}$ \\
\hline Inspections & Used to mitigate likelihood of infestation by specified pest at origin, \\
\hline $\begin{array}{l}\text { Physical treatments on } \\
\text { consignments or during } \\
\text { processing }\end{array}$ & $\begin{array}{l}\text { Used to mitigate likelihood of infestation of pests susceptible to physical } \\
\text { treatments }\end{array}$ \\
\hline Heat and cold treatments & $\begin{array}{l}\text { Used to mitigate likelihood of infestation of pests susceptible to physical } \\
\text { treatments }\end{array}$ \\
\hline Controlled atmosphere & $\begin{array}{l}\text { Used to mitigate likelihood of infestation of pests susceptible to modified } \\
\text { atmosphere (usually applied during transport) hence to mitigate entry }\end{array}$ \\
\hline Conditions of transport & $\begin{array}{l}\text { Used to mitigate likelihood of entry of pests that could otherwise infest } \\
\text { material post-production }\end{array}$ \\
\hline $\begin{array}{l}\text { Phytosanitary certificate and plant } \\
\text { passport }\end{array}$ & $\begin{array}{l}\text { Used to attest which of the above requirements have been applied. If } \\
\text { Leucinodes orbonalis becomes an EU quarantine pest, a phytosanitary } \\
\text { certificate could only be issued if the consignment was found free of the } \\
\text { pest. }\end{array}$ \\
\hline
\end{tabular}

\subsubsection{Biological or technical factors limiting the effectiveness of measures to prevent the entry of the pest}

- Internal feeding in fruit with entry holes sealed make infested fruit difficult to detect unless cut open.

- Resistance to pesticides has developed within L. orbonalis (Ayam et al., 2016; Shirale et al., 2017; Kariyanna et al., 2020) driven by the frequent application of pesticides (e.g. there can be between 56 and 180 applications during the $S$. melongena growing season; Chakraborti and Senapati, 2016).

\subsection{Uncertainty}

The lack of EU outbreaks despite 350 previous interceptions suggests there is uncertainty around the ability of $L$. orbonalis to transfer to a host in a suitable environment after arrival in the EU.

There are uncertainties about the precise environmental limitations within which $L$. orbonalis can survive. This raises uncertainty around the area of the EU where establishment may be possible. Several papers report multiple generations per year in tropical and subtropical conditions with a threshold for development from egg to adult of around $15^{\circ} \mathrm{C}$. However, a single report of $L$. orbonalis occurring at altitudes between 1,200 and $2,000 \mathrm{~m}$ where temperatures drop to $-6.5^{\circ} \mathrm{C}$ during winter months suggests a much wider potential tolerance for cooler climates.

There is uncertainty over the magnitude of potential losses to EU hosts should $L$. orbonalis establish in the EU. 
Most literature focusses on the impact on eggplant, however, Natikar and Balikai (2018) report that serious damage has been recorded on potatoes in south-west India, suggesting $L$. orbonalis is emerging as a pest on another crop. Whether $L$. orbonalis would also cause serious damage to potatoes in the EU is uncertain.

There is some uncertainty regarding non-Solanaceae as hosts given lack of reports in the literature and evidence being based on the interceptions which may be the result of hitchhiking.

\section{Conclusions}

L. orbonalis satisfies the criteria that are within the remit of EFSA to assess for this species to be regarded as a potential Union QP. Table 10 provides a summary of the PLH Panel conclusions.

Table 10: The Panel's conclusions on the pest categorization criteria defined in Regulation (EU) 2016/2031 on protective measures against pests of plants (the number of the relevant sections of the pest categorization is shown in brackets in the first column)

\section{Criterion of pest categorisation}

Identity of the pest (Section 3.1)
Panel's conclusions against criterion in Regulation (EU) 2016/2031 regarding Union quarantine pest

The identity of the species is established and Leucinodes orbonalis Guenée, 1854 is the accepted name and authority.

\section{Key uncertainties}

Taxonomic revision means literature reporting $L$. orbonalis from Africa should be disregarded.

\section{Absence/presence of the pest in the EU (Section 3.2) \\ Regulatory status (Section 3.3) Pest potential for entry, establishment and spread in the EU (Section 3.4)}

\section{Potential for consequences in the EU (Section 3.5) \\ Available measures (Section 3.6)}

\section{Conclusion} (Section 4)

\section{Aspects of} assessment to focus on/scenarios to address in future if appropriate:

\section{References}

Ahmad SI, Pathania SS, Nehru RK and Rouf WA, 2018. Efficacy of management modules against brinjal shoot and fruit borer Leucinodes orbonalis in Kashmir. Indian Journal of Entomology, 80, 527-530.
L. orbonalis is not present in the EU. It is a tropical and sub-tropical species occurring in Asia and Australia.

L. orbonalis is not a regulated EU pest.

L. orbonalis can enter the EU, it has been intercepted 350 times from a range of Asian countries on a range of produce, mostly larvae in fruits of Solanum melongena (eggplants). Biotic factors (host availability) and abiotic factors (climate suitability) suggest that some areas of the EU would be suitable for establishment. Adult $L$. orbonalis can fly and the species could spread within the EU.

The introduction of $L$. orbonalis into the EU could have Magnitude of impact is an economic impact, most likely on S. melongena uncertain production.

Measures are available to prevent the entry, establishment and spread of $L$. orbonalis into and within the EU. For example: Solanaceous plants for planting (other than seed) are already prohibited from entering the EU and host produce require a phytosanitary certificate so must be inspected prior to export

L. orbonalis satisfies the criteria that are within the remit of EFSA to assess for this species to be regarded as a potential Union quarantine pest.

Suggest focus on likelihood of pest transfer following entry to the EU; environmental conditions for establishment, potential overwintering in the $\mathrm{EU}$, the number of generations possible per year and synchrony with hosts to aid evaluation of impacts. 
Akter S, Alam MZ, Rana MS and Saif HB, 2018. Impacts of three pesticides on arthropod biodiversity in brinjal agro-ecosystem. International Journal of Agricultural Research, Innovation and Technology (IJARIT), 8, 55-61.

Alam SN, Rashid MA, Rouf FMA, Jhala RC, Patel JR, Satpathy S, Shivalingaswamy TM, Rai S, Wahundeniya I, Cork A, Ammaranan C and Talekar NS, 2003. Development of an integrated pest management strategy for eggplant fruit and shoot borer in South Asia. Shanhua, Taiwan: AVRDC - the World Vegetable Center. Technical Bulletin No. 28. AVRDC Publication No. 03-548. 56 pp.

Alam SN, Hossain MI, Rouf FM, Jhala RC, Patel MG, Rath LK, Sengupta A, Baral K, Shylesha AN, Satpathy S and Shivalingaswamy TM, 2006. Implementation and promotion of an IPM strategy for control of eggplant fruit and shoot borer in South Asia. AVRDC; 2006. 88 page book. Available online: https://eur03.safelinks.protection. outlook.com/?url=https\%3A\%2F\%2Fassets.publishing.service.gov.uk\%2Fmedia\%2F57a08c42e5274a27b20010ab\% 2FTB36.pdf\&data=04\%7C01\%7C\%7C3fff3ad4ae2440603fbb08d999649cfe\%7C406a174be31548bdaa0acdaddc442 50b\%7C1\%7C0\%7C637709480254043027\%7CUnknown\%7CTWFpbGZsb3d8eyJWIjoiMC4wLjAwMDAiLCJQIjoiV2lu MzIiLCJBTiI6Ik1haWwiLCJXVCI6Mn0\%3D\%7C3000\&sdata=pMpBwdu2LuX6lsKOayTGMdy\%2BbH4i28xSSg7WfXwr GIC\%3D\&reserved=0, https://assets.publishing.service.gov.uk/media/57a08c42e5274a27b20010ab/TB36.pdf

Attygalle AB, Schwarz J and Gunawardena NE, 1988. Sex pheromone of brinjal shoot and pod borer Leucinodis orbonalis Guenée (Lepidoptera: Pyralidae: Pyraustinae). Zeitschrift für Naturforschung C., 43, 790-792.

Ayam AK, Arun S, Chandramani S and Koshta VK, 2016. Detection of insecticidal resistance against various insect pests in vegetable crops at Raipur. International Journal of Plant Protection, 9, 589-592.

Baidoo PK, Mochiah MB, Asare D and Sefah AA, 2018. The role of soil amendments on population dynamics of insect pests, growth parameters and yield of Eggplant, Solanum melongena (L.) Moench. Sustainable Agriculture Research, 7, 7-13.

Baker RHA, 2002. Predicting the limits to the potential distribution of alien crop pests. In: Hallman GJ and Schwalbe CP (eds.). Invasive Arthropods in Agriculture: Problems and Solutions. Science Publishers Inc, Enfield, USA. pp. 207-241.

Boopal K, Arya VV, Reddy PR and Hanur VS, 2013. Potato a suitable alternative host for Brinjal fruit shoot and fruit borer Leucinodes orbonalis Guenee (Lepidoptera: Pyralidae). International Journal of Agricultural Science and Research, 3, 179-184.

Chakraborti S and Senapati A, 2016. Assessing potentiality of a safer approach to manage brinjal fruit and shoot borer. Journal of Entomological Research, 40, 161-168.

Choudhary RS, Rana BS, Meena AK and Naga KL, 2018. Seasonal incidence of Leucinodes orbonalis (Guenee) on brinjal and correlation with abiotic factors. Journal of Entomological Research, 42, 349-354.

Cork A, Alam SN, Rouf FM and Talekar NS, 2003. Female sex pheromone of brinjal fruit and shoot borer, Leucinodes orbonalis (Lepidoptera: Pyralidae): trap optimization and application in IPM trials. Bulletin of Entomological Research, 93, 107-113.

Dhaliwal NK and Aggarwal N, 2021. Development and survival of brinjal shoot and fruit borer Leucinodes orbonalis Guenee (Crambidae: Lepidoptera) at constant and alternating temperatures. International Journal of Tropical Insect Science, 41, 1717-1728.

Dorhout DL, Sappington TW and Rice ME, 2008. Evidence for obligate migratory flight behavior in young European corn borer (Lepidoptera: Crambidae) females. Environmental Entomology, 37, 1280-1290.

EFSA PLH Panel (EFSA Panel on Plant Health), Jeger M, Bragard C, Caffier D, Candresse T, Chatzivassiliou E, Dehnen-Schmutz K, Gregoire J-C, Jaques Miret JA, MacLeod A, Navajas Navarro M, Niere B, Parnell S, Potting R, Rafoss T, Rossi V, Urek G, Van Bruggen A, Van Der Werf W, West J, Winter S, Hart A, Schans J, Schrader G, Suffert M, Kertesz V, Kozelska S, Mannino MR, Mosbach-Schulz O, Pautasso M, Stancanelli G, Tramontini S, Vos $\mathrm{S}$ and Gilioli G, 2018. Guidance on quantitative pest risk assessment. EFSA Journal 2018;16(8):5350, 86 pp. https://doi.org/10.2903/j.efsa.2018.5350

EFSA PLH Panel (EFSA Panel on Plant Health), Bragard C, Di Serio F, Gonthier P, Jaques Miret JA, Justesen AF, Magnusson CS, Milonas P, Navas-Cortes JA, Parnell S, Potting R, Reignault PL, Thulke $\mathrm{H}-\mathrm{H}$, Van der Werf W, Vicent Civera A, Yuen J, Zappalà L, Gregoire JC, Malumphy C, Campese C, Czwienczek E, Kertesz V, Maiorano A and MacLeod A, 2021. Pest categorisation of Leucinodes pseduorbonalis. EFSA Journal 2021;19(11):6889, $21 \mathrm{pp}$. https://doi.org/10.2903/j.efsa.2021.6889

EFSA Scientific Committee, Hardy A, Benford D, Halldorsson T, Jeger MJ, Knutsen HK, More S, Naegeli $H$, Noteborn H, Ockleford C, Ricci A, Rychen G, Schlatter JR, Silano V, Solecki R, Turck D, Benfenati E, Chaudhry QM, Craig P, Frampton G, Greiner M, Hart A, Hogstrand C, Lambre C, Luttik R, Makowski D, Siani A, Wahlstroem H, Aguilera J, Dorne J-L, Fernandez Dumont A, Hempen M, Valtuena Martınez S, Martino L, Smeraldi C, Terron A, Georgiadis N and Younes M, 2017. Scientific Opinion on the guidance on the use of the weight of evidence approach in scientific assessments. EFSA Journal 2017;15(8):4971, 69 pp. https://doi.org/ 10.2903/j.efsa.2017.4971

EPPO (European and Mediterranean Plant Protection Organization), 2019. EPPO codes. Available online: https:// www.eppo.int/RESOURCES/eppo_databases/eppo_codes

EPPO (European and Mediterranean Plant Protection Organization), online. EPPO Global Database. Available online: https://gd.eppo.int [Accessed 24/09/2021]. 
FAO (Food and Agriculture Organization of the United Nations), 2004. ISPM (International Standards for Phytosanitary Measures) 21-Pest risk analysis of regulated non-quarantine pests. FAO, Rome, 30 pp. Available online: https://www.ippc.int/sites/default/files/documents//1323945746_ISPM_21_2004_En_2011-11-29_Refor. pdf

FAO (Food and Agriculture Organization of the United Nations), 2013. ISPM (International Standards for Phytosanitary Measures) 11-Pest risk analysis for quarantine pests. FAO, Rome, $36 \mathrm{pp}$. Available online: https://www.ippc.int/sites/default/files/documents/20140512/ispm_11_2013_en_2014-04-30_201405121523494.65\%20KB.pdf

FAO (Food and Agriculture Organization of the United Nations), 2018. International Standards for Phytosanitary Measures. ISPM 5 Glossary of phytosanitary terms. Revised version adopted CPM 13, April 2018. FAO, Rome. Available online: https://www.ippc.int/en/publications/621/

Fu XW, Li C, Feng HQ, Liu ZF, Chapman JW, Reynolds DR and Wu KM, 2014. Seasonal migration of Cnaphalocrocis medinalis (Lepidoptera: Crambidae) over the Bohai Sea in northern China. Bulletin of Entomological Research, $104,601-609$.

van der Gaag DJ and Stigter H, 2005. Pest Risk Analysis: Leucinodes orbonalis (Guenee). Plant Protection Service, the Netherlands. Available online: https://pra.eppo.int/pra/919917b0-fcde-4116-92fc-e3f6363ebdeb [Accessed: 22 August 2021].

Ghosh SK and Senapati SK, 2009. Seasonal fluctuation in the population of Leucinodes orbonalis Guen. In the subHimalayan region of West Bengal, India and its control on eggplant (Solanum melongena L.). Precision Agriculture, 10, 443-449.

Gilligan TM and Passoa SC, 2014. Fact sheet Leucinodes orbonalis Guenée. Microlepidoptera on Solanaceae. Available online: http://idtools.org/id/leps/micro/factsheet.php?name=\%3Cem\%3Eleucinodes+orbonalis\%3C $\%$ 2Fem\%3E [Accessed: 14 August 2021].

Griessinger D and Roy A-S, 2015. EPPO codes: a brief description. Available online: https://www.eppo.int/media/ uploaded_images/RESOURCES/eppo_databases/A4_EPPO_Codes_2018.pdf

Hayden JE, Lee S, Passoa SC, Young J, Landry J-F, Nazari V, Mally R, Somma LA and Ahlmark KM, 2013. Digital Identification of Microlepidoptera on Solanaceae. USDA-APHIS-PPQ Identification Technology Program (ITP). Fort Collins, CO. Available online: http://idtools.org/id/leps/micro/ [Accessed: 14 August 2021].

Higgott JB, 2009. Leucinodes orbonalis Guenée, 1854 (Lepidoptera: Pyralidae), a species not previously recorded in the wild in Great Britain. Entomologist's Gazette, 60, 25-27.

Hossain MA, Islam Z and Rafiquzzaman M, 2013. Fruit and shoot borer of brinjal. CABI Plantwise Factsheets for Farmers. Available online: https://www.plantwise.org/FullTextPDF/2015/20157800236.pdf

Islam T, Roknuzzaman AH, Hassan K and Ullah MS, 2020. Temperature impacts on the eggplant shoot and fruit borer Leucinodes orbonalis: a life table approach. International Journal of Tropical Insect Science, 40, 351-360.

Javed $\mathrm{H}$, Mukhtar T, Javed $\mathrm{K}$ and ul Mohsin A, 2017. Management of eggplant shoot and fruit borer (Leucinodes orbonalis Guenee) by integrating different non-chemical approaches. Pakistan Journal of Agricultural Sciences, $54,65-70$.

Kariyanna B, Prabhuraj A, Asokan R, Ramkumar G, Venkatesan T, Gracy RG and Mohan M, 2020. Genome mining and functional analysis of cytochrome P450 genes involved in insecticide resistance in Leucinodes orbonalis (Lepidoptera: Crambidae). Biotechnology and Applied Biochemistry. https://doi.org/10.3389/fphys.2020.594845

Karthika P, Vadivalagan C, Thirumurugan D and Murugan K, 2019. Intra-species variation and geographic differentiation among the populations of the quarantine agricultural pest Leucinoides orbonalis (Lepidoptera: Crambidae) in the global assemblage-a prospective of DNA barcoding. Mitochondrial DNA Part A, 30, 682-693.

Katiyar OP and Mukharji SP, 1974. Development of Leucinodes orbonalis Guenée at certain temperatures. Indian Journal of Horticulture, 31, 291-294.

Koundinya AV, Pandit MK and Saha A, 2019. Association of fruit and shoot borer infestation in eggplant with morphological, yield, quality and external weather variables. Agricultural Research, 8, 309-319.

Lall BS and Ahmad SQ, 1965. The biology and control of brinjal (eggplant) fruit and shoot borer, Leucinodes orbonalis. Journal of Economic Entomology, 58, 448-451.

Lal vOP, 1975. Zur Uberwinterung von Leueinodes orbonalis Guen.(Lep., Pyralidae), eines Schadlings der Aubergine, Solanum melongena L., im Kulu-Tal, West-Himalaya, Indien. Anz. Schadlingskde. Pflanzenschutz, Umweltschutz, 48, 181-182.

Latif MA, Rahman MM and Alam MZ, 2010. Efficacy of nine insecticides against shoot and fruit borer, Leucinodes orbonalis Guenee (Lepidoptera: Pyralidae) in eggplant. Journal of pest science, 83, 391-397.

MacLeod A, 2015. The relationship between biosecurity surveillance and risk analysis. Chapter 5, pp. 109-122, In: Jarrad F, Low Chow S and Mengersen K (eds.). Biosecurity Surveillance: Quantitative Approaches. CABI, Wallingford, 374pp +xi.

Mainali RP, 2014. Biology and management of eggplant fruit and shoot borer, Leucinodes orbonalis Guenee (Lepidoptera: Pyralidae). International Journal of Applied Sciences and Biotechnology, 2, 18-28.

Mall NP, Pandey RS, Singh SV and Singh SK, 1992. Seasonal incidence of insect-pests and estimation of the losses caused by shoot and fruit borer on brinjal. Indian Journal of Entomology, 54, 241-247. 
Mally R, Korycinska A, Agassiz DJL, Hall J, Hodgetts J and Nuss M, 2015. Discovery of an unknown diversity of Leucinodes species damaging Solanaceae fruits in sub-Saharan Africa and moving in trade (Insecta, Lepidoptera, Pyraloidea). ZooKeys, 472, 117-162.

Mannan MA, Islam KS, Jahan M and Tarannum N, 2015a. Some biological parameters of brinjal shoot and fruit borer, Leucinodes orbonalis guenee (Lepidoptera: Pyralidae) on potato in laboratory condition. Bangladesh Journal of Agricultural Research., 40, 381-390.

Mannan MA, Islam KS and Jahan M, 2015b. Brinjal shoot and fruit borer infestation in relation to plant age and season. Bangladesh Journal of Agricultural Research, 40, 399-407.

Maureal AM, Carino MFA, Noriel LM and Esguerra NM, 1982. Life history and behaviour of eggplant fruit borer, Leucinodes orbonalis Guenee. Annals of Tropical Research, 4, 178-188.

Mehto DN, Singh KM, Singh RN and Prasad D, 1983. Biology of brinjal fruit and shoot borer, Leucinodes orbonalis Guen. Bulletin of Entomology, 24, 112-115.

Natikar PK and Balikai RA, 2018. Status of insect pests of potato and their natural enemies in Karnataka during rabi season. Journal of Experimental Zoology, India, 21, 1163-1172.

Onekutu A, Omoloye AA and Odebiyi JA, 2013. Biology of the eggfruit and shoot borer (EFSB), Leucinodes orbonalis Guenee (Crambidae) on the garden egg, Solanum gilo Raddi. Journal of Entomology, 10, $156-162$. Available online: https://scialert.net/fulltext/?doi=je.2013.156.162

Shirale D, Patil M and Parimi S, 2017. Insecticide resistance in field populations of Leucinodes orbonalis (Lepidoptera: Crambidae) in India. The Canadian Entomologist, 149, 399-407.

Singh YP and Singh PP, 2003. Biology of shoot and fruit borer (Leucinodes orbonalis Guen.) of eggplant (Solanum melongena L.) at medium high-altitude hills of Meghalaya: (c) weather parameters with the development of shoot and fruit borer. Indian. Journal of Entomology, 65, 147-154 (abstract only).

Singh B, Kumar V, Mahla MK, Vyas AK and Chhangani G, 2019. Efficacy of egg parasitoid in management of brinjal shoot and fruit borer, Leucinodes orbonalis Guenée. Journal of Biological Control, 33, 343-347.

Sultana H, Mannan MA, Kamal MM, Quddus KG and Das S, 2018. Appraisal of resistant genotypes against brinjal shoot and fruit borer (BSFB), Leucinodes orbonalis, Guenee. Journal of the Bangladesh Agricultural University, $16,227-231$.

\section{Abbreviations}

$\begin{array}{ll}\text { EPPO } & \text { European and Mediterranean Plant Protection Organization } \\ \text { FAO } & \text { Food and Agriculture Organization } \\ \text { IPPC } & \text { International Plant Protection Convention } \\ \text { ISPM } & \text { International Standards for Phytosanitary Measures } \\ \text { MS } & \text { Member State } \\ \text { PLH } & \text { EFSA Panel on Plant Health } \\ \text { QP } & \text { quarantine pest } \\ \text { TFEU } & \text { Treaty on the Functioning of the European Union } \\ \text { ToR } & \text { Terms of Reference }\end{array}$

\section{Glossary}

Containment (of a pest)

Control (of a pest)

Entry (of a pest)

Eradication (of a pest)

Establishment (of a pest)

Greenhouse

Impact (of a pest)

Introduction (of a pest) Pathway

Application of phytosanitary measures in and around an infested area to prevent spread of a pest (FAO, 2018).

Suppression, containment or eradication of a pest population (FAO, 2018).

Movement of a pest into an area where it is not yet present, or present but not widely distributed and being officially controlled (FAO, 2018).

Application of phytosanitary measures to eliminate a pest from an area (FAO, 2018).

Perpetuation, for the foreseeable future, of a pest within an area after entry (FAO, 2018).

A walk-in, static, closed place of crop production with a usually translucent outer shell, which allows controlled exchange of material and energy with the surroundings and prevents release of plant protection products (PPPs) into the environment.

The impact of the pest on the crop output and quality and on the environment in the occupied spatial units.

The entry of a pest resulting in its establishment (FAO, 2018).

Any means that allows the entry or spread of a pest (FAO, 2018). 
Phytosanitary measures

Quarantine pest

Risk reduction option (RRO)

Spread (of a pest)
Any legislation, regulation or official procedure having the purpose to prevent the introduction or spread of quarantine pests, or to limit the economic impact of regulated non-quarantine pests (FAO, 2018).

A pest of potential economic importance to the area endangered thereby and not yet present there, or present but not widely distributed and being officially controlled (FAO, 2018).

A measure acting on pest introduction and/or pest spread and/or the magnitude of the biological impact of the pest should the pest be present. A RRO may become a phytosanitary measure, action or procedure according to the decision of the risk manager.

Expansion of the geographical distribution of a pest within an area (FAO, 2018). 


\section{Appendix A - Leucinodes orbonalis host plants and plants affected}

Source: EPPO Global Database (EPPO online) + indicates major host

\begin{tabular}{|c|c|c|c|c|}
\hline Host status & Host name & Plant family & Common name & Reference \\
\hline \multirow[t]{29}{*}{ Cultivated hosts } & Solanum aethiopicum + & Solanaceae & Bitter tomato & \\
\hline & Solanum melongena + & " & Eggplant/aubergine & \\
\hline & Solanum torvum & $"$ & Pea eggplant & Interception data \\
\hline & Capsicum annuum & " & Sweet pepper & \\
\hline & Physalis minima & $"$ & $\begin{array}{l}\text { Wild cape } \\
\text { gooseberry }\end{array}$ & \\
\hline & Physalis peruviana & $"$ & Goldenberry & \\
\hline & Solanum aculeatissimum & $"$ & Dutch eggplant & \\
\hline & Solanum anguivi & $"$ & & \\
\hline & Solanum erianthum & $"$ & Velvet nightshade & \\
\hline & Solanum lycopersicum & $"$ & Tomato & \\
\hline & Solanum macrocarpon & $"$ & African eggplant & \\
\hline & Solanum mammosum & $"$ & Nipplefruit & \\
\hline & Solanum myriacanthum & " & & \\
\hline & Solanum stramoniifolium & $"$ & & Interception data \\
\hline & Solanum tuberosum & $"$ & Potato & \\
\hline & Solanum undatum & $"$ & & Interception data \\
\hline & Solanum virginianum & $"$ & & Interception data \\
\hline & Beta vulgaris & Amaranthaceae & Beet & \\
\hline & Mangifera indica & Anacardiaceae & Mango & \\
\hline & Spondias dulcis & $"$ & Amberella & Interception data \\
\hline & Ipomoea batatas & Convolvulaceae & Sweet potato & \\
\hline & Ipomoea aquatica & $"$ & & Interception data \\
\hline & Momordica sp. & Cucurbitaceae & Bitter melon & Interception data \\
\hline & Pisum sativum & Fabaceae & Pea & \\
\hline & Vigna sp. & $"$ & A bean & Interception data \\
\hline & Ocimum sp. & Lamiaceae & Basil & Interception data \\
\hline & Psidium guajava & Myrtaceae & Guava & Interception data \\
\hline & Murraya paniculata & Rutaceae & Orange jasmine & Interception data \\
\hline & Citrus hystrix & $"$ & Thai lime & Interception data \\
\hline \multirow[t]{2}{*}{ Wild weed hosts } & Solanum nigrum & Solanaceae & Black nightshade & \\
\hline & Solanum viarum & " & Tropical soda apple & \\
\hline $\begin{array}{l}\text { Artificial / experimental } \\
\text { host }\end{array}$ & $\begin{array}{l}\text { Solanum tuberosum } \\
\text { (peeled tubers) }\end{array}$ & $"$ & potato & $\begin{array}{l}\text { Boopal et al. (2013), } \\
\text { Mannan et al. } \\
(2015 a)\end{array}$ \\
\hline
\end{tabular}




\section{Appendix B - Distribution of Leucinodes orbonalis}

Distribution records based on EPPO Global Database (EPPO, online).

\begin{tabular}{|c|c|c|c|}
\hline Region & Country & $\begin{array}{l}\text { Sub-national } \\
\text { (e.g. State) }\end{array}$ & Status \\
\hline \multirow[t]{2}{*}{ EU (27) } & Denmark & & Absent, intercepted only \\
\hline & Netherlands & & Absent, intercepted only \\
\hline Other Europe & UK & & $\begin{array}{l}\text { Absent, has been found in the past but not } \\
\text { established (Higgott, 2009) }\end{array}$ \\
\hline \multirow[t]{20}{*}{ Africa } & Burundi & & Absent, invalid record \\
\hline & Cameroon & & Absent, invalid record \\
\hline & Congo, DRC & & Absent, misidentification of taxonomy \\
\hline & Congo & & Absent, invalid record \\
\hline & Côte d'Ivoire & & Absent, invalid record \\
\hline & Ethiopia & & Absent, invalid record \\
\hline & Ghana & & Absent, invalid record \\
\hline & Kenya & & Absent, invalid record \\
\hline & Lesotho & & Absent, invalid record \\
\hline & Malawi & & Absent, invalid record \\
\hline & Mozambique & & Absent, invalid record \\
\hline & Nigeria & & Absent, invalid record \\
\hline & Rwanda & & Absent, invalid record \\
\hline & $\begin{array}{l}\text { Sao Tome and } \\
\text { Principe }\end{array}$ & & Absent, invalid record \\
\hline & Sierra Leone & & Absent, invalid record \\
\hline & Somalia & & Absent, invalid record \\
\hline & South Africa & & Absent, invalid record \\
\hline & Tanzania & & Absent, invalid record \\
\hline & Uganda & & Absent, invalid record \\
\hline & Zambia & & Absent, invalid record \\
\hline \multirow[t]{21}{*}{ Asia } & Bangladesh & & Present, widespread \\
\hline & Brunei Darussalam & & Present, no details \\
\hline & Cambodia & & Present, no details \\
\hline & China & & Present, restricted distribution \\
\hline & & Guangdong & Zhang et al. (2010) in CABI, online \\
\hline & & Hubei & Present, no details \\
\hline & & Hunan & Present, no details \\
\hline & & Jiangsu & Present, Widespread (CABI, online) \\
\hline & & Jiangxi & Present, no details \\
\hline & & Xianggang (Hong Kong) & Present, no details \\
\hline & India & & Present, widespread \\
\hline & & $\begin{array}{l}\text { Andaman and Nicobar } \\
\text { Islands }\end{array}$ & Present, no details \\
\hline & & Andhra Pradesh & Present, no details \\
\hline & & Assam & Present, widespread \\
\hline & & Bihar & Present, no details \\
\hline & & Chhattisgarh & Present, no details \\
\hline & & Delhi & Present, no details \\
\hline & & Goa & Present, no details \\
\hline & & Gujarat & Present, no details \\
\hline & & Haryana & Present, no details \\
\hline & & Himachal Pradesh & Present, no details \\
\hline
\end{tabular}




\begin{tabular}{|c|c|c|c|}
\hline Region & Country & $\begin{array}{l}\text { Sub-national } \\
\text { (e.g. State) }\end{array}$ & Status \\
\hline & & Jammu and Kashmir & Present, no details \\
\hline & & Jharkhand & $\begin{array}{l}\text { Chang JianCheng et al. (2016) in CABI, } \\
\text { online }\end{array}$ \\
\hline & & Karnataka & Present, no details \\
\hline & & Kerala & Present, no details \\
\hline & & Madhya Pradesh & Present, no details \\
\hline & & Maharashtra & Present, no details \\
\hline & & Manipur & Present, no details \\
\hline & & Meghalaya & Present, no details \\
\hline & & Nagaland & Present, no details \\
\hline & & Odisha & Present, no details \\
\hline & & Punjab & Present, no details \\
\hline & & Rajasthan & Present, no details \\
\hline & & Tamil Nadu & Present, no details \\
\hline & & Tripura & Present, no details \\
\hline & & Uttarakhand & Present, no details \\
\hline & & Uttar Pradesh & Present, no details \\
\hline & & \multirow[t]{2}{*}{ West Bengal } & Present, no details \\
\hline & \multirow[t]{3}{*}{ Indonesia } & & Present, restricted distribution \\
\hline & & Java & Present, no details \\
\hline & & Sumatra & Present, no details \\
\hline & Japan & & Present, no details \\
\hline & Laos & & Present, no details \\
\hline & \multirow[t]{3}{*}{ Malaysia } & & Present, no details \\
\hline & & Sarawak & Present, no details \\
\hline & & West & Present, no details \\
\hline & Myanmar & & Present, no details \\
\hline & Nepal & & Present, no details \\
\hline & Pakistan & & Present, no details \\
\hline & Philippines & & Present, no details \\
\hline & Saudi Arabia & & Present, no details \\
\hline & Singapore & & Present, no details \\
\hline & Sri Lanka & & Present, no details \\
\hline & Taiwan & & Present, no details \\
\hline & Thailand & & Present, no details \\
\hline & United Arab Emirates & & Present, no details \\
\hline & Vietnam & & Present, restricted distribution \\
\hline \multirow[t]{3}{*}{ Oceania } & \multirow[t]{3}{*}{ Australia } & & Present, restricted distribution \\
\hline & & Queensland & Present, no details \\
\hline & & Northern Territory & Present, no details \\
\hline
\end{tabular}




\section{Appendix C - Interception data through time}

EU Interceptions of Leucinodes orbonalis (350 records) and Leucinodes sp. (9 records) from Asia; Jan 2004 to June 2021

\begin{tabular}{|c|c|c|c|c|c|c|c|c|c|c|c|}
\hline Year & 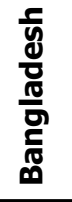 & 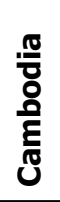 & 疍 & $\begin{array}{l}\frac{5}{\mathbb{1}} \\
\frac{0}{\pi} \\
\text { ñ }\end{array}$ & "ू & $\frac{\frac{\pi}{5}}{\frac{\pi}{\pi}}$ & $\begin{array}{l}\frac{5}{5} \\
\frac{\hbar}{5} \\
\frac{1}{0}\end{array}$ & 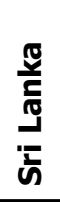 & 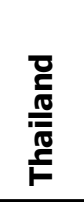 & 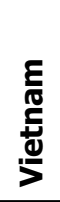 & $\begin{array}{l}E \\
\bar{n}\end{array}$ \\
\hline 2004 & - & - & - & - & - & - & - & - & 23 & - & 23 \\
\hline 2005 & - & - & 3 & - & - & - & - & - & 60 & - & 63 \\
\hline 2006 & - & - & 2 & - & - & - & - & - & 19 & 1 & 22 \\
\hline 2007 & - & - & 10 & - & - & - & - & - & 9 & 4 & 23 \\
\hline 2008 & 4 & - & 7 & - & - & - & - & - & 5 & - & 16 \\
\hline 2009 & 1 & - & 1 & - & - & - & - & 8 & 6 & - & 16 \\
\hline 2010 & 1 & - & - & - & - & - & - & 2 & 11 & - & 14 \\
\hline 2011 & 2 & - & 1 & - & - & 7 & 2 & 6 & 1 & 5 & 24 \\
\hline 2012 & 4 & - & 8 & - & 3 & 13 & 2 & 13 & 1 & - & 44 \\
\hline 2013 & 1 & 2 & 8 & - & - & 8 & 7 & 7 & 1 & - & 34 \\
\hline 2014 & - & 4 & - & - & - & 1 & - & 5 & 1 & 1 & 12 \\
\hline 2015 & - & - & - & - & - & - & - & 1 & - & - & 1 \\
\hline 2016 & - & - & - & - & 1 & - & - & - & - & - & 1 \\
\hline 2017 & - & - & - & - & - & - & - & 1 & - & - & 1 \\
\hline 2018 & - & - & 2 & - & - & - & - & 1 & - & - & 3 \\
\hline 2019 & - & 2 & - & - & - & - & - & - & 3 & 4 & 9 \\
\hline 2020 & - & 6 & 1 & 1 & 4 & - & - & 16 & 4 & - & 32 \\
\hline 2021 & - & 1 & - & - & - & - & - & 19 & 1 & - & 21 \\
\hline Sum & 13 & 15 & 43 & 1 & 8 & 29 & 11 & 79 & 145 & 15 & 359 \\
\hline
\end{tabular}

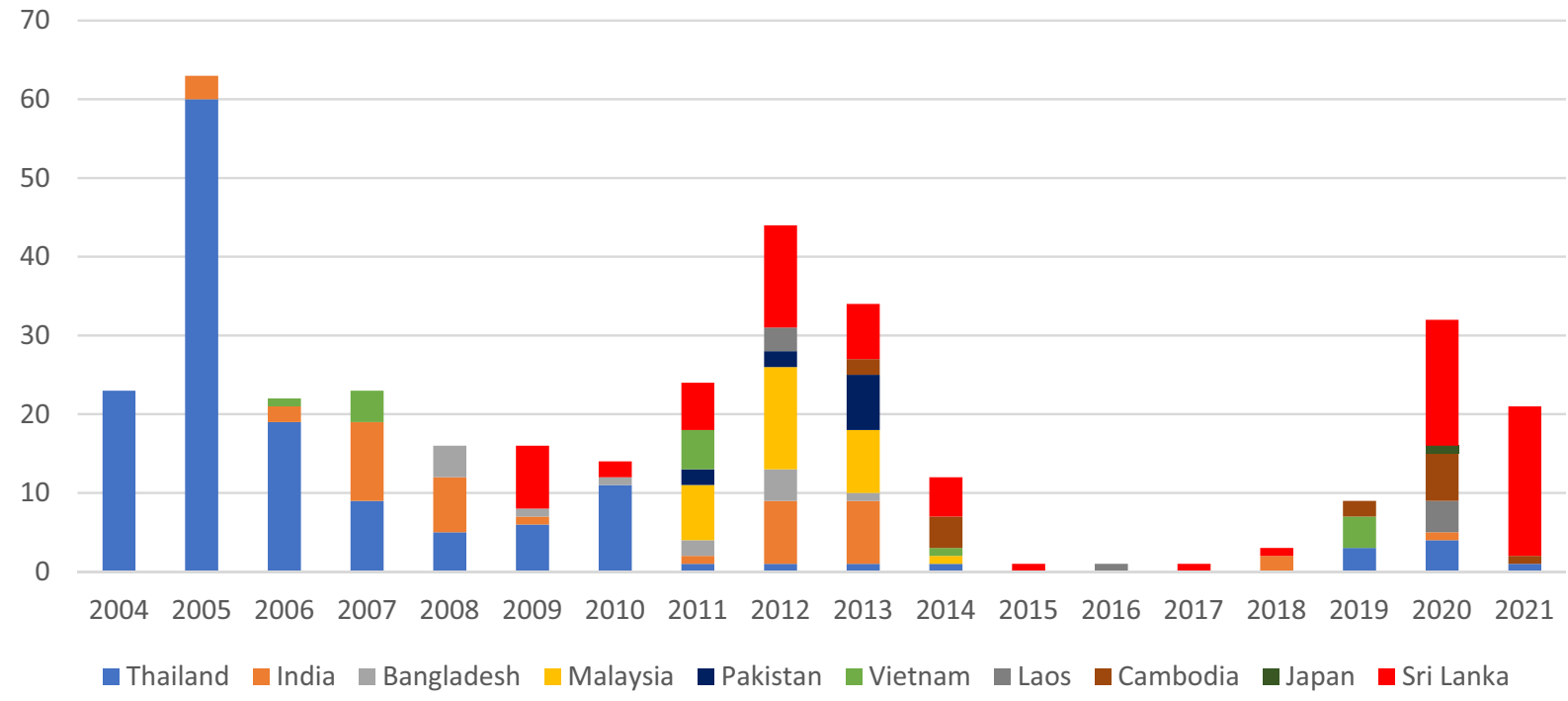




\section{Appendix D - Import data into EU 27}

(Eurostat accessed on 20/7/2021)

Fresh or chilled aubergines 'eggplants' (CN code: 07093000) (Hundreds of kg)

\begin{tabular}{l|c|c|c|c|c}
\hline Country & $\mathbf{2 0 1 6}$ & $\mathbf{2 0 1 7}$ & $\mathbf{2 0 1 8}$ & $\mathbf{2 0 1 9}$ & $\mathbf{2 0 2 0}$ \\
\hline Laos & 623.61 & 507.16 & 553.87 & 651.54 & 575.33 \\
\hline Thailand & 371.71 & 361.70 & 392.81 & 482.10 & 435.44 \\
\hline Viet Nam & 439.72 & 375.63 & 338.35 & 307.70 & 38.43 \\
\hline Malaysia & 319.24 & 368.87 & 253.99 & 213.25 & 7.29 \\
\hline Sri Lanka & 10.30 & 6.57 & 0.35 & 23.51 & 15.29 \\
\hline India & 13.83 & 4.45 & - & 15.61 & 3.25 \\
\hline Pakistan & 0.40 & 0 & 3.85 & 0.48 & 10.60 \\
\hline Indonesia & - & 0 & 0.21 & 2.93 & 10.35 \\
\hline Japan & 0.24 & 1.24 & 0.53 & 1.94 & 0.38 \\
\hline Bangladesh & 0.15 & 1.05 & - & - & - \\
\hline Philippines & - & 0 & - & 0.86 & - \\
\hline China & - & 0 & - & 0.60 & - \\
\hline United Arab Emirates & - & 0 & - & 0.10 & - \\
\hline
\end{tabular}

Tomatoes (CN code: 0702) (Hundreds of $\mathrm{kg}$ )

\begin{tabular}{l|c|c|c|c|c}
\hline Country & $\mathbf{2 0 1 6}$ & $\mathbf{2 0 1 7}$ & $\mathbf{2 0 1 8}$ & $\mathbf{2 0 1 9}$ & $\mathbf{2 0 2 0}$ \\
\hline Japan & 13.75 & 8.98 & 13.31 & 45.67 & 34.37 \\
\hline United Arab Emirates & - & 0.00 & - & 3.77 & - \\
\hline Australia & - & 0.00 & - & 2.52 & - \\
\hline Thailand & 0.08 & 0.08 & 0.08 & 0.02 & 0.02 \\
\hline Viet Nam & 0.03 & 0.06 & - & - & - \\
\hline India & - & 0.00 & - & 0.01 & - \\
\hline
\end{tabular}

Fresh or chilled sweet peppers (CN code: 07096010) (Hundreds of $\mathrm{kg}$ )

\begin{tabular}{l|c|c|c|c|c}
\hline Country & $\mathbf{2 0 1 6}$ & $\mathbf{2 0 1 7}$ & $\mathbf{2 0 1 8}$ & $\mathbf{2 0 1 9}$ & $\mathbf{2 0 2 0}$ \\
\hline Japan & 13.75 & 8.98 & 13.31 & 45.67 & 34.37 \\
\hline United Arab Emirates & - & 0.00 & - & 3.77 & - \\
\hline Australia & - & 0.00 & - & 2.52 & - \\
\hline Thailand & 0.08 & 0.08 & 0.08 & 0.02 & 0.02 \\
\hline Viet Nam & 0.03 & 0.06 & - & - & - \\
\hline India & - & 0.00 & - & 0.01 & - \\
\hline
\end{tabular}

Fresh or chilled peas (CN code: 070810$)$ (Hundreds of $\mathrm{kg}$ )

\begin{tabular}{l|c|c|c|c|c}
\hline Country & $\mathbf{2 0 1 6}$ & $\mathbf{2 0 1 7}$ & $\mathbf{2 0 1 8}$ & $\mathbf{2 0 1 9}$ & $\mathbf{2 0 2 0}$ \\
\hline China & 924.42 & 757.01 & 1442.82 & 1580.7 & 1780.75 \\
\hline Thailand & 100.19 & 74.31 & 87.9 & 153.74 & 85.36 \\
\hline Pakistan & 7.9 & 19.28 & 9.07 & 19.08 & 19.89 \\
\hline Australia & 0 & 0 & - & - & 71.76 \\
\hline India & 4.55 & 16.14 & 0.74 & 1.5 & 22 \\
\hline Bangladesh & 2.25 & 5.8 & - & - & 3.95 \\
\hline Laos & 1.32 & 0.01 & - & - & 6.13 \\
\hline Japan & 0.13 & 0.07 & 4.48 & 0.01 & 0.02 \\
\hline Nepal & - & 0.5 & - & - & 1.92
\end{tabular}




\begin{tabular}{l|c|c|c|c|c}
\hline Country & $\mathbf{2 0 1 6}$ & $\mathbf{2 0 1 7}$ & $\mathbf{2 0 1 8}$ & $\mathbf{2 0 1 9}$ & $\mathbf{2 0 2 0}$ \\
\hline Cambodia & - & 0 & - & 1.73 & 0.04 \\
\hline United Arab Emirates & - & 0 & - & 1.4 & - \\
\hline Viet Nam & 0.02 & 0 & - & 0.19 & 0.55 \\
\hline Sri Lanka & - & 0.48 & - & - & 0.05 \\
\hline
\end{tabular}

